\title{
Shaping the size of a neuronal lineage: the role of Imp and Syp RBPs in the precise elimination of neurons by apoptosis.
}

\author{
Wenyue Guan ${ }^{1}$, Mathilde Bouchet ${ }^{1}$, Aurélien Darmas ${ }^{1}$ and Jonathan Enriquez ${ }^{1,2 *}$ \\ ${ }^{1}$ Institut de Génomique Fonctionnelle de Lyon, ENS de Lyon, CNRS, Univ Lyon 1, 46 Allée d'Italie, \\ ${ }^{2}$ Lead Contact \\ *Correspondence: jonathan.enriquez@ens-lyon.fr (J.E.)
}

\section{SUMMARY}

Neuronal stem cells produce a finite and stereotyped number of neuronal progenies. This process must be finely regulated during development and adult stages to ensure proper brain function. In Drosophila, stem cells, called Neuroblasts, produce an invariant number of neurons. Two RNA binding proteins, Imp and Syp, play a central role in controlling the speed of division and the end of the proliferative phase of individual NBs, two parameters that influences the final number of neurons produced. Here, we have discovered a novel function for Imp and Syp, where both RBPs also-shape the number of neurons produced by a stem cell by controlling program cell death (PCD) in immature neurons. By studying a neuroblast lineage, called Lin $\mathrm{A} / 15$, which produces motoneurons (MNs) and glia, we have demonstrated that Lin A/15 stem cell spends $40 \%$ of its time producing immature MNs which are eliminated by apoptosis. We have revealed that only the first born MNs $(\operatorname{Imp}+)$ survive while the last born MNs (Imp- Syp+) are eliminated by apoptosis. Both RBPs play a central role in neuronal survival, Imp promotes neuronal survival while Syp promotes cell death in immature motoneurons. Interestingly their opposite temporal gradient in Lin A/15 stem cell also determines the end of Lin A/15 stem cell neurogenesis by PCD. Both RNA binding proteins are conserved in vertebrates and seem to play a central role in the number of neurons produce during development. The Drosophila model and its genetic tools offer a unique chance to decipher their function in neural stem cell versus immature neurons. 
bioRxiv preprint doi: https://doi.org/10.1101/2021.11.06.467542; this version posted November 8,2021 . The copyright holder for this preprint (which was not certified by peer review) is the author/funder, who has granted bioRxiv a license to display the preprint in perpetuity. It is made available under aCC-BY-NC-ND 4.0 International license.

\section{INTRODUCTION}

The central nervous system (CNS) receives information from the periphery, records and processes it to control different types of behavior such as communication, thought or locomotion. A complex network of neurons and glia, produced mainly during development by neuronal stem cells, ensures all these functions. Each neuronal stem cell produces at the right time and in the correct position a finite number of neurons and glia with diverse identities. The precise production of neurons and glia by stem cells must be finely and precisely tuned because any dysregulation of the molecular machinery controlling this developmental process can lead to serious brain disorders or cancers. An increase or a decrease of adult neurogenesis in humans can cause psychiatric disorders such as schizophrenia (Allen et al., 2016; Mahar et al., 2014) and autism (Hazlett et al., 2017; 2010) or neurodegenerative diseases such as Alzheimer (Gallardo, 2019). Many brain tumors feature a disruption of neurodevelopmental programs and child tumors that develop early after birth are probably due to a dysregulation of the molecular machinery controlling neurogenesis termination (Jessa et al., 2019). Identifying new mechanisms controlling the correct number of neuronal and glial cells is not only essential for understanding the development of biological systems or the genesis of human disease, but also for understanding how the architecture and function of the CNS evolves. Recent studies in insects suggest that the variation in the number of neurons during evolution contributes to changes in neuronal circuits and therefore behaviors (Pop et al., 2020; Prieto-Godino et al., 2020). In our study, using Drosophila, we identified a new mechanism participating in the control of the correct number of neurons produced during development.

In Drosophila, adult neurons and glia are mostly produced during larval and pupal stages by stem cells called Neuroblast (NB). As in vertebrates, NBs divide asymmetrically to renew themselves and to produce directly or indirectly neuronal and glia progenies. Two major types of NBs produce most adult neurons and glia in Drosophila (Harding and White, 2018; Homem et al., 2015). Type I NBs produce an intermediate cell called ganglion mother cell (GMC) that divide once to produce neurons and glia (Doe et al., 1985; Karcavich and Doe, 2005) while type II neuroblasts produce an intermediate neuronal progenitor (INP) that divide several times to produce glia and/or neurons (Bello et al., 2008; Bowman et al., 2008; Homem et al., 2015). When flies are raised in normal conditions, each NB generates a stereotyped number of mature neurons that vary from NB to NB. The production of a stereotypic number of progenies depends mainly on three parameters that are the speed of NB division, the timing of NB neurogenesis termination and programed cell death (PCD) during the asymmetric division of the GMCs. Diverse molecular mechanisms described below regulate these three parameters.

Each NB producing adult neuron or glia terminates their proliferative phase at different time points via two distinct mechanisms. Most type I and II NBs terminate neurogenesis at early pupal stages by nuclear accumulation of the transcription factor (TF) Prospero, which induces the symmetrical division of NBs that gives rise to two postmitotic cells (Homem et al., 2014; Maurange et al., 2008). On the other hand, in the mushroom body, a structure playing a role in olfactory learning and memory, neurons are produced by type INBs ending their proliferative phase at late pupal stages by a combination of autophagy and PCD (Pahl et al., 2019; Siegrist et al., 2010). Before the termination of neurogenesis, all NBs decrease in size (Homem et al., 2014; Maurange et al., 2008). The decrease in size of the NBs ending neurogenesis early uncouple cell growth and division due to a metabolism switch that increase oxidative phosphorylation that end up to a terminal differentiation division (Homem et al., 2014). On the other hand, the decrease in size of the mushroom body NBs, which end neurogenesis at late pupal stages, is correlated to a decrease of phosphatidylinositol 3-Kinase activity (PI3K) activity, an inhibitor of autophagy (Homem et al., 2014; Pahl et al., 2019). The termination of NB neurogenesis by autophagic cell death or by a terminal differentiation is called decommissioning. The timing of decommissioning is under the control of extrinsic signal such as the steroid hormone ecdysone (Homem et al., 2014; Pahl et al., 2019) and an intrinsic program of two RNA binding proteins (RBPs), Imp (IGF-II mRNA binding proteins) and Syp (Syncrip), expressed in opposite temporal gradient in the NB. For example, MB NBs 
bioRxiv preprint doi: https://doi.org/10.1101/2021.11.06.467542; this version posted November 8, 2021. The copyright holder for this preprint (which was not certified by peer review) is the author/funder, who has granted bioRxiv a license to display the preprint in perpetuity. It is made available under aCC-BY-NC-ND 4.0 International license.

decommission at late pupal stage due to a protracted expression of Imp compared to other NBs (Yang et al., 2017). The consequence on neuronal production of early or late decommissioning has not been characterized due to the lack of genetic tools available to study the neuroblast progenies in different genetic condition.

The speed of NB division is also a parameter molecularly controlled that could impact the number of cells produced by a lineage. The average speed of NB divisions in the larvae is around 80-90 mins per division (Hailstone et al., 2020; Homem et al., 2013), however this speed varies from NB to NB (Hailstone et al., 2020). The heterogeneity of NB division speed seems also to be regulated by the opposite temporal gradient of Imp and Syp in the NB. Imp stabilizes myc RNA leading to an increase of Myc protein and therefore to a high-speed of division. Syp protein has an opposite effect on NB division speed by directly inhibiting Imp as development passes (Samuels et al., 2020).

Moreover, it has been shown that PCD functions as another driving force sculpting the final clonal size of each lineage. Between $40 \%$ and $50 \%$ of the hemi-lineages of type I NB died by PCD (Kumar et al., 2009; Truman et al., 2010). Interestingly, when PCD is blocked in the midline NBs of the ventral nerve cord (VNC: analogue of our spinal cord) the 'undead' neurons differentiate and elaborate complex and functional arborizations (Pop et al., 2020). Recent studies have demonstrated how variation in PCD patterns between different insect species could change their behavior suggesting that probably all mechanisms controlling the number of neurons potentially play a role during the behavior evolution (Pop et al., 2020; Prieto-Godino et al., 2020).

The heterogeneous physiology of NBs, including their proliferation ending as well as the proliferation rate, may account for different number of neurons produced by individual NBs. However, it has not been investigated due to the lack of genetic reagents tracing progenies of individual NBs. In our study, we genetically trace the progeny a single NB (Awasaki et al., 2014, Lacin and Truman, 2016) , named Lin A (also called Lin 15) NB, in order to discover new mechanisms controlling the precise number of neurons produced by a stem cell. Lin A/15 NB produces in each ganglion 29 adult motoneurons (MNs) innervating leg muscles $(2 / 3$ of the adult motoneurons produced during larval stages) and most astrocytes and ensheathing glia of the thoracic ganglion (Baek and Mann, 2009; Brierley et al., 2012; Enriquez et al., 2018) (Fig. 1A-B4). During larval stages, Lin A/15 NB divides in a particular manner that we called type Ib (Fig. 1C-G). During the first phase of division Lin A/15 NB produces intermediate mother cells (IMCs) that give rise to a postmitotic cell and a proliferative glioblast (Fig. 1G). Lin A/15 switches, during a second phase, to a classical mode of type I division where only postmitotic MNs are generated (Fig. 1G) (Enriquez et al., 2018). After development, an adult Lin A/15 is composed by a stereotyped number of MNs (Fig. 1F). Interestingly Lin A/15 NB produces an excess of neurons during larval stages that are precisely eliminated before the adult stage (Fig. 1F). The molecular machinery controlling the timely and precise elimination of these neurons is unknown.

Here, we demonstrate that the opposite expression pattern of Imp and Syp in immature MNs shapes, in synergy with their function in the NB, the number of neurons produced by a stem cell by controlling the spatio-temporal pattern of PCD. We first demonstrated that, after producing Glia and MNs, Lin A/15 GMCs produce a postmitotic MN and a sibling cell eliminated by PCD soon after their birth. This mode of division continues until the decommissioning by PCD of Lin A/15 NB resulting in the production of supernumerary MNs. The excess of MNs are progressively and precisely eliminated by PCD from early pupal stages until the end of Lin A/15 neurogenesis to reach the final number of 29 MNs. The elimination of postmitotic MNs is not stochastic but deterministic since only the last born MNs are removed by PCD. The decommissioning Lin A/15 NB and the MNs eliminated by PCD are Imp- and Syp+. Our genetic manipulations revealed that changing the temporal pattern in the NB and the spatial pattern in immature MNs of Imp and Syp change the timing of NB decommissioning and the number of immature MNs surviving receptively. Previous studies and our work cements the role of Imp and Syp as two multitasking proteins that can modulate the number of neuronal cells trough different mechanisms: the 
bioRxiv preprint doi: https://doi.org/10.1101/2021.11.06.467542; this version posted November 8,2021 . The copyright holder for this preprint (which was not certified by peer review) is the author/funder, who has granted bioRxiv a license to display the preprint in perpetuity. It is made available under aCC-BY-NC-ND 4.0 International license.

timing NB decommissioning (Yang et al., 2017) and NB division speed (Samuels et al., 2020) and the number of MNs surviving (this work).

\section{RESULTS}

\section{Lin A/15 switches to a classical type I division during larval stages where the GMC produces one $\mathrm{MN}$ and a dying cell.}

Lin $\mathrm{A} / 15$ produces MNs and glia during the first phase of NB division and only MNs during a second phase. It has been suggested that during the second phase Lin A/15 GMCs could produce a MN and an apoptotic sibling cell (Truman et al., 2010).

We precisely characterized Lin A/15 development by labeling it with GFP during the first and the second phase of NB division by using a Lin A/15 tracing system (Awasaki et al., 2014, Lacin and Truman, 2016) and immuno-stained it against a cleaved form of the Drosophila caspase-1 (cDcp1), an apoptotic marker (Fig. 2). During the first phase, 64-73 hours After Egg Laying (AEL), no cDcp1+ cells were observed, confirming our previous study that during early developmental stages Lin A/15 NB produces an intermediate mother cell (IMC) that divides once to produce a glioblast and a postmitotic MN (Fig. 2A1-A3) (Enriquez et al., 2018). During the second phase, 77-120 hours AEL, apoptotic cells cDcp1+ Elav- were detected close to Dpn+ Lin A/15 NB (Dpn and Elav are NB and postmitotic neuronal markers respectively), suggesting that $\mathrm{PCD}$ occurs soon after asymmetric division. The absence of Elav in the apoptotic cells also suggested that the sibling cells die before acquiring a neuronal identity (Fig. 2B1F3). Consistent with this idea, we then generated Lin A/15 MARCM clones to label all Lin A/15 cells with GFP under the control of a tub-Gal4 transgene, and VGlut+ MNs with mCherry by using VGlutLexA::GAD (MI04979), a gene trap transgene of the gene coding for the vesicular glutamate transporter expressed by all Drosophila MNs. We dissected late third instar larva (LL3) and observed that cDcp1+ Elav- cells did not express VGlut (Fig. 2G1-G3).

Together, our results show that Lin A/15 GMCs produce a MN and a sibling cell eliminated by PCD during the second phase of Lin A division (Fig. 2H). Moreover, PCD of the sibling cell occurs soon after birth before they express neuronal marker such as Elav or VGlut.

\section{Lin A/15 NB decommissions 24h after pupa formation through PCD}

We subsequently explored the development of Lin A/15 during the pupal stages to determine when the NB stops producing MNs and terminates neurogenesis.

We genetically labeled Lin A/15 with GFP and performed an immunostaining against Dpn to label Lin $\mathrm{A} / 15 \mathrm{NB}$ and against phospho-Histone $\mathrm{H} 3$ (PH3), a marker of cell proliferation. We revealed that Lin $\mathrm{A} / 15 \mathrm{NB}(\mathrm{PH} 3+/ \mathrm{Dpn}+)$ continues proliferating from 0 hour after pupa formation (APF) until 20 hours APF (Fig. 3A1-C2). During early pupal stages cDcp1+ Elav- cells were also detected suggesting that Lin A/15 NB keep producing a GMC that divides once into a MN and an apoptotic cell (Fig. S1). At 24 hours APF, Lin A/15 NB is no longer detected in most of our samples (N=4/17, Number of Lin A/15 with a NB), revealing the end of Lin A/15 neurogenesis at this stage. Similar to what has been shown for other NBs, the volume of Lin A/15 NB decreases throughout development until the termination of Lin A/15 neurogenesis (Fig. S2). At 24 hours APF, the remaining Lin A/15 NBs are extremely small and express cDcp1 suggesting a decommissioning of Lin A/15 NB through PCD (Fig. 3D). To confirm this result we then inhibited PCD in Lin A/15 by using the baculovirus P35 protein, an inhibitor of apoptosis in insect (Hay et al., 1994). Under these experimental conditions, Lin A/15 NB survived at least until 28 APF (Fig. 3E-G). Furthermore we didn't detect autophagic markers in the NB such as Atg8 and LysoTracker (Mauvezin et al., 2014) suggesting that the PCD of the NB is not linked to autophagy such as the mushroom body NBs (Fig. S3).

Our results reveal that Lin $\mathrm{A} / 15 \mathrm{NB}$ continues producing MNs during early pupal stages and, unlike most NBs described in the thoracic segments of the VNC (Maurange et al., 2008), Lin A/15 NB finishes its proliferative phase through PCD at 24 hours APF in all thoracic ganglions (Fig. 3H). 
bioRxiv preprint doi: https://doi.org/10.1101/2021.11.06.467542; this version posted November 8,2021 . The copyright holder for this preprint (which was not certified by peer review) is the author/funder, who has granted bioRxiv a license to display the preprint in perpetuity. It is made available under aCC-BY-NC-ND 4.0 International license.

Opposite temporal gradients of Imp and Syp control the timing of Lin A/15 NB decommissioning We then investigated if Imp and Syp could control the timing of decommissioning of Lin A/15 NB.

We first analyzed the expression pattern of Imp and Syp in Lin A/15 NB throughout Lin A/15 neurogenesis. Imp is highly expressed in Lin A/15 NB during early L3 stages while Syp protein is not detectable (70-80 hours AEL) (Fig. 4A1-A2, F1-F2). Lin A/15 NB begins to express Syp at mid-L3 larval stages while the expression of Imp starts to decrease (94-97 hours AEL) (Fig. 4B1-B2, G1-G2). At the end of the larval stages, Imp/Syp expression pattern in Lin A/15 NB is reversed with Imp and Syp weakly and highly expressed respectively (Fig. 4C1-C2, H1-H2). This opposite expression of Imp and Syp is accentuated during pupal stages where Imp protein is no longer detected in the NB just before decommissioning (Fig. 4D1-E2, I1-J2). The prolonged expression of Imp or knocking-down Syp extended the lifespan of Lin A/15 NB until young adult stages and at least 28 hours APF respectively (Fig. 5G1-O2, , Q) while knocking-down Imp in Lin A/15 NB induced a premature decommissioning at 20 hours APF (Fig. 5A1-F1, P). Moreover, the control of the timing of Lin A/15 NB decommissioning by the temporal expression of Imp/Syp is similar in all thoracic segments.

Our results show that the sequential expression of Imp and Syp controls the timing of the decommissioning of Lin $\mathrm{A} / 15 \mathrm{NB}$ that terminates neurogenesis by apoptosis in all thoracic segments (Fig. 4K).

\section{The last-born neurons produced by Lin A/15 are eliminated by PCD.}

The number of Lin A/15 MNs, which is extremely stereotyped between adult flies, is gradually established during development (Fig.1F and Fig. 6D). Lin A/15 reaches the maximum number of Elav + neurons at 0 hour APF ( $=39, \mathrm{SD}=2$, Number of Lin A/15 Elav+ neurons) (Fig. 6D). Even though Lin A/15 NB keeps dividing at early pupal stages (Fig. 3A-3C), the number of Elav + neurons progressively decreases until 24 hours APF to almost reach the final number of MNs $(\mathrm{N}=32, \mathrm{SD}=1$ at 24 hour APF compared to adult: $\mathrm{N}=29, \mathrm{SD}=1$ ) (Fig. 6D).

We genetically labeled Lin A/15 with GFP and performed an immunostaining against Dpn, Elav and cDcp1 during pupal stages to determine if the supernumerary postmitotic MNs are eliminated by PCD (Fig. 6A1-C4). Unlike thelarval stages, we detected Elav+ cDcp1+ neurons close to the NB suggesting that the last-born Elav + neurons are progressively eliminated by apoptosis from 0 hours to 24 hours APF (Fig. 6A1-C4). To demonstrate that the last born MNs are eliminated by PCD we fed L3 larvae with Edu to only label the late born MNs and dissected CNS at early pupal stage (5 hours APF) (Fig. 6E1E7). We observed that the first born MNs were $\mathrm{Edu}-(\mathrm{N}=30, \mathrm{SD}=2$, Number of Edu- MNs at 5 hours APF) and distant from the NB while the last born MNs $(\mathrm{N}=7, \mathrm{SD}=2$, Number of Edu + MNs at 5 hours APF) were Edu+ and close to the NB (Fig. 6E5-E6). We revealed that cDcp1+ Elav+ neurons were always Edu+ and we never observed cDcp1+ Edu- neurons (N=16, Number of Lin A/15 analyzed). We also dissected CNSs at late pupal stage (17 hours APF) to monitor the residual Edu labeled MNs and we observed a significant decrease of the Elav $+\mathrm{Edu}+\mathrm{MNs}(\mathrm{N}=2, \mathrm{SD}=2$, Number of Edu + MNs at 17 hours APF), indicating a progressive elimination of all those late-born MNs (Fig. 6F). Both results reveal that the last-born MNs die through PCD during pupal stages (Fig. 6E1-F).

We then inhibited apoptosis in MNs by ectopically expressing the antiapoptotic gene $P 35$ to confirm that the supernumerary MNs are eliminated by PCD. We used the MARCM technique with the VGlutGal4 (also called OK371-Gal4) enhancer trap driver to express P35 in the supernumerary immature neurons. This driver is only expressed in Lin A/15 Elav+ cells (Fig. 6H) and by consequence $V G l u t>P 35$ should failed to inhibit apoptosis in the Elav-cells eliminated by PCD after the GMC division while it should inhibit apoptosis of the last-born MNs during pupal stage. As predicted with this genetic manipulation, similar numbers of neurons were produced in L3 larvae in Lin A/15 MARCM clone expressing P35 compared to WT Lin A/15 while more Lin A MNs survive into adult (Fig. 6GH). 
bioRxiv preprint doi: https://doi.org/10.1101/2021.11.06.467542; this version posted November 8,2021 . The copyright holder for this preprint (which was not certified by peer review) is the author/funder, who has granted bioRxiv a license to display the preprint in perpetuity. It is made available under aCC-BY-NC-ND 4.0 International license.

Our results demonstrate that the elimination by PCD of the supernumerary MNs is not stochastic. Only last-born neurons are precisely and progressively eliminated by PCD during pupal stages from 0 hour APF to 24 hours APF (Fig. 6L).

Opposite spatial gradients of Imp and Syp in postmitotic Neurons determine the pattern of PCD The serially derived neuronal progenies inherit the Imp and Syp levels from the NB, thus an opposite spatial gradients of Imp and Syp is formed in postmitotic MNs (Imp is highly present in first born MNs and Syp is highly abundant in late born MNs) (Fig 4A-J). Importantly, during the pupal stages, sthe last born Lin A/15 MNs that are eliminated by PCD are Imp- and Syp+ (Fig. 7A1-A5). These observations suggest that the opposite expression pattern of the two RBPs in postmitotic neurons could determine the final number of adult MNs surviving. We then explored the possibility that Imp and Syp not only control the size of a lineage through their temporal function in the NB (Fig.5) but also by controlling PCD in postmitotic neurons.

Our genetic tools not only allow us to study the decommissioning of Lin $\mathrm{A} / 15 \mathrm{NB}$ under different genetic condition but also to precisely investigate the destiny of its progeny. The prolonged expression of Imp or knocking-down Syp in Lin A/15 NB and in its progeny inhibited PCD of the supernumerary neurons (Fig. 7B, 7E1-J3). On the contrary, knocking-down Imp in Lin A/15 induced premature PCD of Elav+ MNs during larval stages (Fig. 7C1-D3) and an increase of the number of Elav + neurons eliminated by PCD during Pupal stages (Fig. 7B1). All these genetic experiments, which modified the level of Imp and Syp in the NB and its postmitotic progenies changed the final number of neurons produced by Lin $\mathrm{A} / 15$ (Fig 7K) by changing the timing of NB decommissioning and the pattern of PCD in postmitotic neurons (Fig 6-7). The modulation of PCD pattern in postmitotic neurons by Imp and Syp could result from an autonomous function in postmitotic MNs or by a change of the temporal identity of Lin A/15 NB. To uncouple their function in the NB and in MNs, we ectopically expressed Imp in postmitotic neurons, including the supernumerary MNs, without affecting its expression in Lin A/15 NB by using the MARCM technique with the VGlut-Gal4 enhancer trap driver. Under this experimental condition more Lin A MNs are maintained in adult flies (Fig 6L-N), implying a cell autonomous function in postmitotic MNs of Imp in promoting cell survival of MNs.

Our results reveal that the opposite expression pattern of Imp and Syp in postmitotic neurons precisely shape the size of Lin A/15 by controlling the pattern of PCD in immature MNs (Fig. 8).

\section{DISCUSSION}

\section{Imp and Syp, lineage size ruler}

The timing of neurogenesis termination is crucial to define how many neurons are produced during development by a given stem cell. Our genetic tool tracing a single lineage allowed us to demonstrate that changing the timing of NB decommissioning changes the number of neurons produced by a stem cell. We showed in our study that two intrinsic temporal factors, Imp and Syp, are actively involved in defining the final clonal size of a lineage by signaling timely apoptosis of NB. Some studies have revealed that intrinsic mechanism and external cues control Imp/Syp expression pattern in brain NBs. In some brain lineages Imp and Syp cross-repress each other (Liu et al., 2015; Syed et al., 2017) and this cross repression is modulated by external cues such as the ecdysone hormone (Homem et al., 2014) or activins (Rossi and Desplan, 2020). The mutual inhibition between Imp and Syp is not observed in Lin A/15 NB, suggesting that Imp/Syp-independent mechanism(s) govern their sequential expression in Lin A/15 NB (Fig S4).

More importantly, by studying the development of a single neuronal lineage, we revealed that the spatial expression pattern of Imp and Syp in postmitotic neurons is also important to define the size of a lineage by regulating PCD. The expression of Imp/Syp in immature MNs is correlated to their temporal expression in the NB, first born neurons express high levels of Imp whereas last born neurons express high levels of Syp. Interestingly, both RPBs are actively expressed in immature MNs showing that their 
bioRxiv preprint doi: https://doi.org/10.1101/2021.11.06.467542; this version posted November 8, 2021. The copyright holder for this preprint (which was not certified by peer review) is the author/funder, who has granted bioRxiv a license to display the preprint in perpetuity. It is made available under aCC-BY-NC-ND 4.0 International license.

expression in immature MNs is not just the perturbance of their expression in the NB (Guan et al., 2021). Do they maintain their expression in immature MNs by inheriting determinants from the NB? If yes, are these determinants acting directly on Imp/Syp expression or do they give MNs the capacity to respond to external cues such as the ecdysone hormone? We hypothesize that postmitotic MNs, as such in the $\mathrm{NB}$, has the capacity to respond to external cues as this might explain why the MNs are eliminated during early pupal stages when ecdysone is highly expressed (Warren et al., 2006).

\section{Imp and Syp, highly versatile RBPs in specifying neuronal identity and lineage sizes}

Imp and Syp are multitasking proteins acting on different parameters of the NB: their sequential expression in brain NBs controls their temporal identity (Liu et al., 2015; Syed et al., 2017), the timing of NB decommissioning (Yang et al., 2017) and speed division (Samuels et al., 2020). In the brain, their opposing temporal expression in the Mushroom Body NBs shapes the expression pattern of Chinmo transcription factor from high to low, which in turn determines the identity of the neuronal progeny in function of its concentration. We have recently discovered that Imp/Syp controls the morphology of Lin A/15 MNs not only by determining the temporal identity of the neuroblast but also by shaping a combinatorial code of morphological transcription factors (mTFs) in postmitotic MNs which in turn control their morphologies (Guan et al., 2021). Interestingly Imp/Syp seem also to control the expression of terminal selector genes. Initially defined in C. elegans, terminal selector are TFs maintaining the expression of proteins, such as neurotransmitter or neuropeptide, that are essential for the neurons to function (Allan et al., 2005; Eade et al., 2012; Hobert, 2011, 2016). In the Mushroom Body, Imp/Syp shape the terminal molecular features fate by regulating the terminal selector Mamo (Liu et al., 2019). All these data revealed that Imp/Syp are multitasking proteins that act in the NB and its progeny during neurogenesis ensuring reliable production of a specific number of neurons with unique identities.

Our data highlight that both RBPs control two parameters in postmitotic neurons, neuronal diversity and neuronal survival. Are these two parameters directly linked? The effectors of Imp/Syp determining the morphologies of MNs are mTFs while the downstream effectors of Imp/Syp controlling PCD patterns remain to be identified. Our recent work shows that depletion of some mTFs results in less MNs persistent into adult fly (Guan et al., 2021), suggesting that functional TF codes are necessary for neuronal survival. This also raise the possibility that mTFs serve as effectors of Imp/Syp that coordinate both neuronal identity and neuronal survival. Why an excess of MNs are produced? Why do neurons dye during development? PCD occurs in all animal model studied in laboratories, from C. elegans to Vertebrates and many explanations have been proposed to explain why such mechanism have been selected during evolution (Dekkers et al., 2013; Oppenheim, 1991). The widespread PCD during neurodevelopment raises an appealing hypothesis that neurons normally fated to die represent an important reservoir that can be used during evolution to explore different morphological possibilities, where different $\mathrm{mTF}$ code can be tested, without affecting the axon-muscle connectome, until a functional combination of $\mathrm{mTF}$ is selected.

\section{Imp/Syp proteins in development and disease.}

Imp and Syp are evolutionarily conserved, both homologs are highly expressed in the developing mouse brain and play vital roles in neural development, suggesting a fundamental conservation of their function in the development of central nervous (Chen et al., 2012; Mori et al., 2001; Williams et al., 2016). For example, Imp1, one of the three mouse orthologues of Imp family, is highly expressed in young neuronal progenitors. Its temporal expression with other RBP partners changes the temporal identity of the neuronal stem cells. In particular Imp promotes the self-renewal state of neuronal stem cells while inhibiting differentiation genes (Nishino et al., 2013).

As mentioned in the introduction, any dysregulation of the machinery controlling neuronal stem cell physiology can have dramatic consequences. For example dysregulation of the RBPs expression are a common feature of neurodegenerative diseases (Lenzken et al., 2014). Interestingly, the Imp family also plays a key role in the stem cell physiology of many other organs (Toledano, H., 2012) and several studies have revealed that the Imp family maintain the proliferative state of different type of cancesr 
bioRxiv preprint doi: https://doi.org/10.1101/2021.11.06.467542; this version posted November 8,2021 . The copyright holder for this preprint (which was not certified by peer review) is the author/funder, who has granted bioRxiv a license to display the preprint in perpetuity. It is made available under aCC-BY-NC-ND 4.0 International license.

(Bell et al., 2013, Degrauwe et al., 2016, Genovese et al., 2019; Lan et al., 2021; Sun et al., 2021). The powerful genetic tools available in Drosophila allow us to decipher their functions in the stem cells versus postmitotic neurons which is a first step not only to better understand how the organ is built but also to decipher the genesis of cancer and neurodegenerative diseases.

\section{EXPERIMENTAL PROCEDURES}

Key resources table

\begin{tabular}{|c|c|c|}
\hline REAGENT or RESOURCE & SOURCE & IDENTIFIER \\
\hline \multicolumn{3}{|l|}{ Antibodies } \\
\hline rabbit anti-Dcp1 & Cell signaling & Cat\# 9578S; RRID:AB_2721060 \\
\hline mouse anti-Elav & DSHB & Cat\#9F8A9; RRID:AB_2314364 \\
\hline rat anti-Elav & DSHB & Cat\#7E8A10; RRID:AB_528218 \\
\hline mouse anti-repo & DSHB & RRID:AB_528448 \\
\hline rabbit anti-PH3 & Abcam & RRID:AB_2164915 \\
\hline guinea-pig anti-Dpn & Gift from Jim Skeath & N/A \\
\hline goat anti-mouse Alexa 647 & Invitrogen & Cat\#A32728; RRID:AB 2633277 \\
\hline donkey anti-rat Alexa 647 & Jackson & Cat\#712-605-153; RRID:AB_2340694 \\
\hline goat anti-mouse Alexa 555 & Invitrogen & Cat\#A32727; RRID:AB_2633276 \\
\hline goat anti-rabbit Alexa 555 & Invitrogen & Cat\#A32732; RRID:AB_2633281 \\
\hline goat anti-Rat Alexa 555 & Abcam & Cat\#ab150166 \\
\hline $\begin{array}{l}\text { donkey anti-guinea-pig } \\
\text { DyLight } 405\end{array}$ & Jackson & Cat\#706-475-148; RRID:AB_2340470 \\
\hline \multicolumn{3}{|c|}{ Chemicals, peptides, and recombinant proteins } \\
\hline formaldehyde & Thermo Scientific & Cat\#28908 \\
\hline PBS & Dutscher & Cat\#X0515-500 \\
\hline triton & Sigma & Cat\#T8787-100mL \\
\hline BSA & Sigma & Cat\#A7906-500 g \\
\hline Vectashield mounting medium & Vector Laboratories & Cat\#H1000 \\
\hline \multicolumn{3}{|l|}{ Critical commercial assays } \\
\hline Clicl-iT EdU imaging kit & Invitrogen & Cat\#C10340 \\
\hline \multicolumn{3}{|c|}{ Experimental models: Organisms/strains } \\
\hline UAD-KD (attP2[68A4]) & Awasaki et al., 2014 & $\mathrm{~N} / \mathrm{A}$ \\
\hline $\begin{array}{l}\text { Dpn }>\text { KDRT-stop-KDRT }>\text { CRE } \\
(\mathrm{su}(\mathrm{Hw}) \text { attP8[8E10]) }\end{array}$ & Awasaki et al., 2014 & $\mathrm{~N} / \mathrm{A}$ \\
\hline $\begin{array}{l}\text { act }>\text { loxP-stop-loxP }>\text { LexA::P65 } \\
(\text { attP40[25C7]) }\end{array}$ & Lactin and Truman., 2016 & N/A \\
\hline $\begin{array}{l}\text { lexAop-myr::GFP } \\
(\mathrm{su}(\mathrm{Hw}) \mathrm{ttP}[50 \mathrm{~F} 1])\end{array}$ & Awasaki et al., 2014 & $\mathrm{~N} / \mathrm{A}$ \\
\hline $\begin{array}{l}\text { R10c12-GAL4 (3rd chromosome, } \\
\text { attp2) }\end{array}$ & Lactin and Truman., 2016 & N/A \\
\hline $\begin{array}{l}\text { lexAop-Imp-RNAi } \\
\text { (attP40[25C7]) }\end{array}$ & Ren et al.,2017 & N/A \\
\hline lexAop-Imp-RM (attP40[25C7]) & Ren et al.,2017 & N/A \\
\hline $\begin{array}{l}\text { lexAop-Syp-RNAi } \\
\text { (attP40[25C7]) }\end{array}$ & Ren et al.,2017 & N/A \\
\hline tub-gal4 (3rd chromosome,79A2) & $\begin{array}{l}\text { Bloomington Drosophila } \\
\text { Stock Center }\end{array}$ & BDSC: 5138 \\
\hline $\begin{array}{l}\text { DVGlut-Gal4 (2nd chromosome, } \\
\text { 22E1) }\end{array}$ & $\begin{array}{l}\text { Bloomington Drosophila } \\
\text { Stock Center }\end{array}$ & BDSC: 26160 \\
\hline $\begin{array}{l}\text { DVGlut-LexA::GAD } \\
\text { (VGlutMI04979) }\end{array}$ & This study & N/A \\
\hline $\begin{array}{l}\text { UAS-P35 (2nd and 3rd } \\
\text { chromosome) }\end{array}$ & $\begin{array}{l}\text { Bloomington Drosophila } \\
\text { Stock Center }\end{array}$ & BDSC: $5072 ; 5073$ \\
\hline
\end{tabular}




\begin{tabular}{|l|l|l|}
\hline $\begin{array}{l}\text { 20XUAS-Imp-RM-Flag (3rd } \\
\text { chromosome) }\end{array}$ & Liu et al., 2015 & N/A \\
\hline $\begin{array}{l}\text { actin^FRT-stop- } \\
\text { FRT^Gal4 }\end{array}$ & Gift from Alain Garces & N/A \\
\hline Recombinant DNA & Cat\#78307 \\
\hline $\begin{array}{l}\text { pBS-KS-attB2-SA(2)-T2A- } \\
\text { LexA::GADfluw-Hsp70 vector }\end{array}$ & Addgene \\
\hline \multicolumn{2}{|l|}{ Software and algorithms } & https://www.fei.com/ \\
\hline Amira 3D software (version 6.2) & SCR_007353 & https://imagej.nih.gov/ij/ \\
\hline ImageJ (version 1.48) & Schneider et al., 2012 & $\begin{array}{l}\text { https://www.graphpad.com/scientific- } \\
\text { software/prism/ }\end{array}$ \\
\hline GraphPad (Prism 8) & SCR_002798 &
\end{tabular}

\section{Fly stains}

Lin A/15 NB tracing system (all Figures):

LinA/15 restrictive labeling is achieved by immortalizing Gal4 expression in Lin $\mathrm{A} / 15$ neuroblasts and its descendants (Awasaki et al. 2014; Lacin and Truman. 2016). The following fly strains were crossed to specifically label LinA:

10c12-GAL4 crossed with Dpn $>K D R T$-stop-KDRT $>C R E$; act $>$ loxP-stop-loxP $>$ LexA: $: P 65$; lexAopmyr::GFP; UAS-KD.

The following fly strains were used to over-express and knock-down genes (Figure 5, 7):

Dpn $>K D R T$-stop-KDRT>CRE; act>loxP-stop-loxP>LexA::P65; lexAop-myr ::GFP; UAS-KD crossed with LexAop-Imp-Flag/Cyo; 10c12-GAL4/TM6B to overexpress Imp

With LexAop-Syp-RNAi/Cyo; 10c12-GAL4/TM6B to knock-down Syp

With LexAop-Imp-RNAi/Cyo; 10c12-GAL4/TM6B to knock-down Imp

\section{Lin A/15 MARCM:}

Genetic to label with GFP all Lin A cells and with mCherry $V G l u t+$ Elav+ neurons (Figure 2):

y,w, hs-Flp1.22; DVGlut-LexA::GAD, FRT42D, LexO-mCherry/Cyo;tub-GAL4/TM6B crossed to y,w, hs-Flp1.22; DVGlut-Gal4, UAS-mCD8::GFP, Mhc-RFP, FRT42D tub-Gal80/Cyo; UAS$m C D 8:: G F P / M K R S$

Genetic to inhibit apoptosis in immature postmitotic neurons (Figure 6):

y,w,hs-Flp ${ }^{1.22}$; DVGlut-Gal4, UASmCD8::GFP, Mhc-RFP FRT42D/Cyo; TM6B/MKRS crossed to $y$, w,hs-Flp ${ }^{1.22} ; \quad$ DVGlut-GAL4, UAS-mCD8::GFP, Mhc-RFP, FRT42D tub-Gal80/Cyo ; UASP35/TM6B.

Genetic to over express Imp only in postmitotic neurons (Figure 7) :

y,w,hs-Flp ${ }^{1.22}$; DVGlut-Gal4, UASmCD8::GFP, Mhc-RFP FRT42D/Cyo; TM6B/MKRS crossed with $y$,w,hs-Flp ${ }^{1.22}$; DVGlut-GAL4, UAS-mCD8::GFP, Mhc-RFP, FRT42D tub-Gal80/Cyo ; UAS-Flag-Imp$R M / T M 6 B$.

First-instar larvae $(0 \sim 12 \mathrm{~h} \mathrm{ALH})$ were heat shocked at $37^{\circ} \mathrm{C}$ for 20 minutes to induce mosaic clones in $\mathrm{L} 3$ larvae and at $35^{\circ} \mathrm{C}$ for $15 \mathrm{~min}$ to induce mosaic clones in adults.

\section{Vglut-LexA::GAD transgenic line}

The Vglut-LexA ::GAD transgenic line is generated by the Trojan-mediated conversion of MIMIC (Trojan-MiMIC) technique (Diao et al., 2015). A pBS-KS-attB2-SA(2)-T2A-LexA::GADfluw-Hsp70 Plasmid ( addgene plasmid \#78307) was injected into embryos of flies bearing intronic MiMIC inserts 
bioRxiv preprint doi: https://doi org/10.1101/2021.11.06.467542; this version posted November 8,2021 . The copyright holder for this preprint (which was not certified by peer review) is the author/funder, who has granted bioRxiv a license to display the preprint in perpetuity. It is made available under aCC-BY-NC-ND 4.0 International license.

at VGlut gene (VGlutMI04979) together with phiC31 integrase on the genetic background. G0 flies were crossed with flies from the $\mathrm{yw} ; \mathrm{Sp} / \mathrm{CyO} ; \mathrm{Dr} / \mathrm{TM} 3$,Sb double balancer line, and $\mathrm{y}$ - recombinant progeny, which had lost the $\mathrm{y}+$ selection marker associated with the MiMIC insertion, were isolated. The integrase-dependent exchange of T2A-LexA::GAD-containing cassette produce a LexA::GAD driver line that having an expression pattern corresponding to that of VGlut.

\section{Immunostaining}

\section{Immunosstaining of larval and pupal CNS}

Inverted L3 larvae or open pupae were fixed in 4\% paraformaldehyde in PBS for 20 minutes at room temperature and blocked in the blocking buffer for one hour. L3 larval or pupal CNS were carefully dissected in PBS and then incubated with primary antibodies overnight $(>=12 \mathrm{~h})$ and secondary antibodies in dark for one day $\left(>=12 \mathrm{~h}\right.$ ) at $4^{\circ} \mathrm{C}$. Fresh PBST-BSA (PBS with $0.1 \%$ Triton X-100, $1 \%$ BSA) was used for the blocking, incubation, and washing steps: five times for 20 minutes at room temperature after fixation and after primary/secondary antibodies. Larval/pupal CNS were mounted onto glass slides using Vectashield anti-fade mounting medium (Vector Labs). Slides were either imaged immediately or stored at $4^{\circ} \mathrm{C}$.

\section{Immunosstaining of adult VNC}

After removing the abdominal and head segments, the thorax of the flies were opened and fixed in $4 \%$ paraformaldehyde in PBS for 25 minutes at room temperature and blocked in the blocking buffer for one hour. After dissection, adult VNC were incubated with primary antibodies for one day and secondary antibodies in dark for one day at $4^{\circ} \mathrm{C}$. Fresh PBST-BSA (PBS with $0.1 \%$ Triton X-100, $1 \%$ BSA) was used for the blocking, incubation, and washing steps: five times for 20 minutes at room temperature after fixation and after primary/secondary antibodies. VNC were mounted onto glass slides using Vectashield anti-fade mounting medium (Vector Labs). Slides were either imaged immediately or stored at $4^{\circ} \mathrm{C}$.

\section{Primary and secondary antibodies}

The primary antibodies used in this study include: mouse anti-Elav (DSHB-9F8A9), rat anti-Elav (DSHB-7E8A10), mouse anti-Repo (DSHB- 8D12), rabbit anti-cDcp1 (CellSignaling-9578), rabbit anti-PH3 (Abcam-ab80612), guinea-pig anti-Dpn (gift from Jim skeath, Skeath et al., 2017), rat antiImp and rabbit anti-Syp (gifts from Chris Doe).

The secondary antibodies used in this study include: goat anti-Mouse Alexa 647 (Invitrogen-A32728), donkey anti-rat Alexa 647 ( Jackson- 712-605-153), goat anti-Mouse Alexa 555 (Invitrogen-A32727), goat anti-Rabbit Alexa 555 (Invitrogen-A32732), goat anti-Rat Alexa 555 (Abcam-ab150166), donkey anti-guinea-pig DyLight405 (Jackson- 706-475-148).

\section{Image acquisition}

Multiple $0,5-\mu \mathrm{m}$-thick (with exceptions of $1-\mu \mathrm{m}$-thick for Figure6 H-K and Figure L-M) sections in the $\mathrm{z}$ axis (ventro-dorsal for larval/pupal CNS or adult VNC) were imaged with a Leica TCS SP8 or a Zeiss LSM 780 confocal microscope. Binary images for $\mathrm{z}$ stack images were generated using NIH ImageJ.

\section{5-ethynyl-2'deoxyuridine (EdU) labelling (Figure 6)}

To mark late-born MNs, mid-third-instar larvae (98h-104h ALH) were transferred from standard fly food to fly food containing $250 \mathrm{mM}$ EdU. Pupae were then dissected at indicated time points. Open pupae were fixed in 4\% paraformaldehyde in PBS for 20 minutes at room temperature, followed by a quick wash with PBST (PBS with $0.1 \%$ Triton X-100). Edu labeling was then detected using Clicl-iT EdU imaging kit (Invitrogen) according to manufacture's instructions. An immunostaing was then performed as described in the Immunostaining section.

\section{Neuroblast volume}


bioRxiv preprint doi: https://doi org/10.1101/2021 11.06.467542. this version posted November 8, 2021. The copyright holder for this preprint (which was not certified by peer review) is the author/funder, who has granted bioRxiv a license to display the preprint in perpetuity. It is made available under aCC-BY-NC-ND 4.0 International license.

Each Lin A/15 NB was segmented in 3D in ImageJ/Fiji (Rueden et al., 2017; Schindelin et al., 2012; Schneider et al., 2012), using the LimeSeg plugin (Machado et al., 2019), on the GFP channel, with the following parameters: D_0 4-6, F pressure $=0.01, Z$ Z scale $=6.8$, Range in d0 units $\sim 4-6$, Number of integration step $=-1$, real $X Y$ pixel size $=50$. The volume of each segemented cel was used to make the graph on (Fig. S2).

\section{Quantification and statistical analysis}

Graphs of the relative position of each LinA/15 cells were generated with Microsoft Excel. The spatial coordinates were assigned to each cell using the cell counter plug-in of NIH ImageJ software. The coordinates of each cell were normalized with Microsoft Excel in order to have the position of the Lin A NB at the origin of the plot graph. For samples without NB labeled (as in Figure6 C1 and Figure7 $\mathrm{H} 3$ ), the coordinates of each cell were then normalized to a cell located ventrally (as the cDcp1 positive cell in Figure6 C1 and Figure7 H3).

The plots of of the number of Elav + cells (Figure1F, 6D, 6G,7K, 7N), Elav + Edu + cells (Figure 6F) and Elav + cDcp 1 cells (Figure 7B1,7B2), as well as the graph for frequency of NB (Figure 5P and 5Q) were generated with Prism (GraphPad Software). All bar errors represent standard deviation of a minimum of 7 samples, each dot represents a single sample analyzed. Otherwise, the sample size used for each genotype is indicated on the graph or in the text and/or the figures legends. Student's $t$-test (Figure $1 \mathrm{~F}, 6 \mathrm{D}, 6 \mathrm{~F}, 6 \mathrm{G}, 7 \mathrm{~B}, 7 \mathrm{~K}$ and $7 \mathrm{~N}$ ) or Fisher's test (Figure 5P-Q) was performed to compare the difference in between indicated groups. Differences of $\mathrm{P}<0.05$ were considered significant. ${ }^{*} 0.01<\mathrm{P}<0.05$; $* * 0.001<\mathrm{P}<0.01 ; * * * 0.0001<\mathrm{P}<0.001 . * * * * \mathrm{P}<0.0001$.

All schematic were done with Microsoft PowerPoint (Figure1G, Figure2H, Figure3G,Figure4K and Figure 6L).

\section{ACKNOWLEDGMENTS}

We thanks Alain Vincent, Filipe Pinto-Teixeira and Cédric Maurange for comments on the manuscript. We acknowledge the contribution of SFR Biosciences (UAR3444/CNRS, US8/Inserm, ENS de Lyon, UCBL): Arthro-tool facility. We thanks the the IGFL facility platform. This work was funded by the Atip-Avenir program, FRM (\#AJE20170537445) and AFM (\#21999) to J.E. 
bioRxiv preprint doi: https://doi.org/10.1101/2021.11.06.467542; this version posted November 8,2021 . The copyright holder for this preprint (which was not certified by peer review) is the author/funder, who has granted bioRxiv a license to display the preprint in perpetuity. It is made available under aCC-BY-NC-ND 4.0 International license.

\section{REFERENCES}

Allan, D.W., Park, D., St. Pierre, S.E., Taghert, P.H., and Thor, S. (2005). Regulators Acting in Combinatorial Codes Also Act Independently in Single Differentiating Neurons. Neuron 45, 689-700.

Allen, K.M., Fung, S.J., and Weickert, C.S. (2016). Cell proliferation is reduced in the hippocampus in schizophrenia. Aust. N. Z. J. Psychiatry 50, 473-480.

Awasaki, T., Kao, C.-F., Lee, Y.-J., Yang, C.-P., Huang, Y., Pfeiffer, B.D., Luan, H., Jing, X., Huang, Y.-F., He, Y., et al. (2014). Making Drosophila lineage-restricted drivers via patterned recombination in neuroblasts. Nat. Neurosci. 17, 631-637.

Baek, M., and Mann, R.S. (2009). Lineage and birth date specify motor neuron targeting and dendritic architecture in adult Drosophila. J. Neurosci. Off. J. Soc. Neurosci. 29, 6904-6916.

Bell, J.L., Wächter, K., Mühleck, B., Pazaitis, N., Köhn, M., Lederer, M., and Hüttelmaier, S. (2013). Insulin-like growth factor $2 \mathrm{mRNA}$-binding proteins (IGF2BPs): post-transcriptional drivers of cancer progression? Cell. Mol. Life Sci. 70, 2657-2675.

Bello, B.C., Izergina, N., Caussinus, E., and Reichert, H. (2008). Amplification of neural stem cell proliferation by intermediate progenitor cells in Drosophila brain development. Neural Develop. 3, 5 .

Bowman, S.K., Rolland, V., Betschinger, J., Kinsey, K.A., Emery, G., and Knoblich, J.A. (2008). The Tumor Suppressors Brat and Numb Regulate Transit-Amplifying Neuroblast Lineages in Drosophila. Dev. Cell 14, 535-546.

Brierley, D.J., Rathore, K., VijayRaghavan, K., and Williams, D.W. (2012). Developmental origins and architecture of Drosophila leg motoneurons. J. Comp. Neurol. 520, 1629-1649.

Chen, H.-H., Yu, H.-I., Chiang, W.-C., Lin, Y.-D., Shia, B.-C., and Tarn, W.-Y. (2012). hnRNP Q regulates Cdc42-mediated neuronal morphogenesis. Mol. Cell. Biol. 32, 2224-2238.

Degrauwe, N., Suvà, M.-L., Janiszewska, M., Riggi, N., and Stamenkovic, I. (2016). IMPs: an RNAbinding protein family that provides a link between stem cell maintenance in normal development and cancer. Genes Dev. 30, 2459-2474.

Dekkers, M.P.J., Nikoletopoulou, V., and Barde, Y.-A. (2013). Death of developing neurons: New insights and implications for connectivity. J. Cell Biol. 203, 385-393.

Diao, F., Ironfield, H., Luan, H., Diao, F., Shropshire, W.C., Ewer, J., Marr, E., Potter, C.J., Landgraf, M., and White, B.H. (2015). Plug-and-Play Genetic Access to Drosophila Cell Types using Exchangeable Exon Cassettes. Cell Rep. 10, 1410-1421.

Doe, C.Q., Kuwada, J.Y., Goodman, C.S., Gardner, R.L., and Lawrence, P.A. (1985). From epithelium to neuroblasts to neurons: the role of cell interactions and cell lineage during insect neurogenesis. Philos. Trans. R. Soc. Lond. B Biol. Sci. 312, 67-81.

Eade, K.T., Fancher, H.A., Ridyard, M.S., and Allan, D.W. (2012). Developmental transcriptional networks are required to maintain neuronal subtype identity in the mature nervous system. PLoS Genet. 8, e1002501.

Enriquez, J., Rio, L.Q., Blazeski, R., Bellemin, S., Godement, P., Mason, C., and Mann, R.S. (2018). Differing Strategies Despite Shared Lineages of Motor Neurons and Glia to Achieve Robust Development of an Adult Neuropil in Drosophila. Neuron 97, 538-554.e5.

Gallardo, G. (2019). Neurogenesis takes a hit in Alzheimer's disease. Sci. Transl. Med. 11. 
bioRxiv preprint doi: https://doi.org/10.1101/2021.11.06.467542; this version posted November 8,2021 . The copyright holder for this preprint (which was not certified by peer review) is the author/funder, who has granted bioRxiv a license to display the preprint in perpetuity. It is made available under aCC-BY-NC-ND 4.0 International license.

Genovese, S., Clément, R., Gaultier, C., Besse, F., Narbonne-Reveau, K., Daian, F., Foppolo, S., Luis, N.M., and Maurange, C. (2019). Coopted temporal patterning governs cellular hierarchy, heterogeneity and metabolism in Drosophila neuroblast tumors. ELife 8.

Guan, W., Bellemin, S., Bouchet, M., Venkatasubramanian, L., Guillermin, C., Laurençon, A., Chérif, K., Darmas, A., Godin, C., Urdy, S., et al. (2021). The post-transcriptional regulation of TFs in immature motoneurons shapes the axon-muscle connectome. BioRxiv 2021.10.22.465474.

Hailstone, M., Waithe, D., Samuels, T.J., Yang, L., Costello, I., Arava, Y., Robertson, E., Parton, R.M., and Davis, I. (2020). CytoCensus, mapping cell identity and division in tissues and organs using machine learning. ELife 9, e51085.

Harding, K., and White, K. (2018). Drosophila as a Model for Developmental Biology: Stem Cell-Fate Decisions in the Developing Nervous System. J. Dev. Biol. 6.

Hay, B.A., Wolff, T., and Rubin, G.M. (1994). Expression of baculovirus P35 prevents cell death in Drosophila. Dev. Camb. Engl. 120, 2121-2129.

Hazlett, H.C., Gu, H., Munsell, B.C., Kim, S.H., Styner, M., Wolff, J.J., Elison, J.T., Swanson, M.R., Zhu, H., Botteron, K.N., et al. (2017). Early brain development in infants at high risk for autism spectrum disorder. Nature 542, 348-351.

Hobert, O. (2011). Regulation of terminal differentiation programs in the nervous system. Annu. Rev. Cell Dev. Biol. 27, 681-696.

Hobert, O. (2016). Terminal Selectors of Neuronal Identity. Curr. Top. Dev. Biol. 116, 455-475.

Homem, C.C., Repic, M., and Knoblich, J.A. (2015). Proliferation control in neural stem and progenitor cells. Nat. Rev. Neurosci. 16, 647-659.

Homem, C.C.F., Reichardt, I., Berger, C., Lendl, T., and Knoblich, J.A. (2013). Long-Term Live Cell Imaging and Automated 4D Analysis of Drosophila Neuroblast Lineages. PLOS ONE 8, e79588.

Homem, C.C.F., Steinmann, V., Burkard, T.R., Jais, A., Esterbauer, H., and Knoblich, J.A. (2014). Ecdysone and Mediator Change Energy Metabolism to Terminate Proliferation in Drosophila Neural Stem Cells. Cell 158, 874-888.

Jessa, S., Blanchet-Cohen, A., Krug, B., Vladoiu, M., Coutelier, M., Faury, D., Poreau, B., De Jay, N., Hébert, S., Monlong, J., et al. (2019). Stalled developmental programs at the root of pediatric brain tumors. Nat. Genet. 51, 1702-1713.

Karcavich, R., and Doe, C.Q. (2005). Drosophila neuroblast 7-3 cell lineage: a model system for studying programmed cell death, Notch/Numb signaling, and sequential specification of ganglion mother cell identity. J. Comp. Neurol. 481, 240-251.

Kumar, A., Bello, B., and Reichert, H. (2009). Lineage-specific cell death in postembryonic brain development of Drosophila. Development 136, 3433-3442.

Lacin, H., and Truman, J.W. (2016). Lineage mapping identifies molecular and architectural similarities between the larval and adult Drosophila central nervous system. ELife 5, e13399.

Lan, Y., Su, J., Xue, Y., Zeng, L., Cheng, X., and Zeng, L. (2021). Analysing a Novel RNA-BindingProtein-Related Prognostic Signature Highly Expressed in Breast Cancer. J. Healthc. Eng. 2021, 9174055 . 
bioRxiv preprint doi: https://doi.org/10.1101/2021.11.06.467542; this version posted November 8,2021 . The copyright holder for this preprint (which was not certified by peer review) is the author/funder, who has granted bioRxiv a license to display the preprint in perpetuity. It is made available under aCC-BY-NC-ND 4.0 International license.

Lenzken, S.C., Achsel, T., Carrì, M.T., and Barabino, S.M.L. (2014). Neuronal RNA-binding proteins in health and disease. WIREs RNA 5, 565-576.

Liu, L.-Y., Long, X., Yang, C.-P., Miyares, R.L., Sugino, K., Singer, R.H., and Lee, T. (2019). Mamo decodes hierarchical temporal gradients into terminal neuronal fate. ELife 8.

Liu, Z., Yang, C.-P., Sugino, K., Fu, C.-C., Liu, L.-Y., Yao, X., Lee, L.P., and Lee, T. (2015). Opposing intrinsic temporal gradients guide neural stem cell production of varied neuronal fates. Science 350,317-320.

Machado, S., Mercier, V., and Chiaruttini, N. (2019). LimeSeg: a coarse-grained lipid membrane simulation for 3D image segmentation. BMC Bioinformatics 20, 2.

Mahar, I., Bambico, F.R., Mechawar, N., and Nobrega, J.N. (2014). Stress, serotonin, and hippocampal neurogenesis in relation to depression and antidepressant effects. Neurosci. Biobehav. Rev. 38, 173-192.

Maurange, C., Cheng, L., and Gould, A.P. (2008). Temporal Transcription Factors and Their Targets Schedule the End of Neural Proliferation in Drosophila. Cell 133, 891-902.

Mauvezin, C., Ayala, C., Braden, C.R., Kim, J., and Neufeld, T.P. (2014). Assays to monitor autophagy in Drosophila. Methods 68, 134-139.

Mori, H., Sakakibara, S., Imai, T., Nakamura, Y., Iijima, T., Suzuki, A., Yuasa, Y., Takeda, M., and Okano, H. (2001). Expression of mouse igf2 mRNA-binding protein 3 and its implications for the developing central nervous system. J. Neurosci. Res. 64, 132-143.

Nishino, J., Kim, S., Zhu, Y., Zhu, H., and Morrison, S.J. (2013). A network of heterochronic genes including Imp1 regulates temporal changes in stem cell properties. ELife 2, e00924.

Oppenheim, R.W. (1991). Cell Death During Development of the Nervous System. Annu. Rev. Neurosci. 14, 453-501.

Pahl, M.C., Doyle, S.E., and Siegrist, S.E. (2019). E93 Integrates Neuroblast Intrinsic State with Developmental Time to Terminate MB Neurogenesis via Autophagy. Curr. Biol. 29, 750-762.e3.

Pop, S., Chen, C.-L., Sproston, C.J., Kondo, S., Ramdya, P., and Williams, D.W. (2020). Extensive and diverse patterns of cell death sculpt neural networks in insects. ELife 9, e59566.

Prieto-Godino, L.L., Silbering, A.F., Khallaf, M.A., Cruchet, S., Bojkowska, K., Pradervand, S., Hansson, B.S., Knaden, M., and Benton, R. (2020). Functional integration of "undead" neurons in the olfactory system. Sci. Adv. 6, eaaz7238.

Rossi, A.M., and Desplan, C. (2020). Extrinsic activin signaling cooperates with an intrinsic temporal program to increase mushroom body neuronal diversity. ELife 9, e58880.

Rueden, C.T., Schindelin, J., Hiner, M.C., DeZonia, B.E., Walter, A.E., Arena, E.T., and Eliceiri, K.W. (2017). ImageJ2: ImageJ for the next generation of scientific image data. BMC Bioinformatics 18,529 .

Samuels, T.J., Järvelin, A.I., Ish-Horowicz, D., and Davis, I. (2020). Imp/IGF2BP levels modulate individual neural stem cell growth and division through myc mRNA stability. ELife 9, e51529.

Schindelin, J., Arganda-Carreras, I., Frise, E., Kaynig, V., Longair, M., Pietzsch, T., Preibisch, S., Rueden, C., Saalfeld, S., Schmid, B., et al. (2012). Fiji: an open-source platform for biological-image analysis. Nat. Methods 9, 676-682. 
bioRxiv preprint doi: https://doi.org/10.1101/2021.11.06.467542; this version posted November 8,2021 . The copyright holder for this preprint (which was not certified by peer review) is the author/funder, who has granted bioRxiv a license to display the preprint in perpetuity. It is made available under aCC-BY-NC-ND 4.0 International license.

Schneider, C.A., Rasband, W.S., and Eliceiri, K.W. (2012). NIH Image to ImageJ: 25 years of image analysis. Nat. Methods 9, 671-675.

Siegrist, S.E., Haque, N.S., Chen, C.-H., Hay, B.A., and Hariharan, I.K. (2010). Inactivation of both Foxo and reaper promotes long-term adult neurogenesis in Drosophila. Curr. Biol. CB 20, 643-648.

Skeath, J.B., Wilson, B.A., Romero, S.E., Snee, M.J., Zhu, Y., and Lacin, H. (2017). The extracellular metalloprotease AdamTS-A anchors neural lineages in place within and preserves the architecture of the central nervous system. Dev. Camb. Engl. 144, 3102-3113.

Sun, C., Zheng, X., Sun, Y., Yu, J., Sheng, M., Yan, S., Zhu, Q., and Lan, Q. (2021). Identification of IGF2BP3 as an Adverse Prognostic Biomarker of Gliomas. Front. Genet. 12, 743738.

Syed, M.H., Mark, B., and Doe, C.Q. (2017). Steroid hormone induction of temporal gene expression in Drosophila brain neuroblasts generates neuronal and glial diversity. ELife 6, e26287.

Truman, J.W., Moats, W., Altman, J., Marin, E.C., and Williams, D.W. (2010). Role of Notch signaling in establishing the hemilineages of secondary neurons in Drosophila melanogaster. Development 137, 53-61.

Warren, J.T., Yerushalmi, Y., Shimell, M.J., O’Connor, M.B., Restifo, L., and Gilbert, L.I. (2006). Discrete Pulses of Molting Hormone, 20-Hydroxyecdysone, During Late Larval Development of Drosophila melanogaster: Correlations With Changes in Gene Activity. Dev. Dyn. Off. Publ. Am. Assoc. Anat. 235, 315-326.

Wegiel, J., Kuchna, I., Nowicki, K., Imaki, H., Wegiel, J., Marchi, E., Ma, S.Y., Chauhan, A., Chauhan, V., Bobrowicz, T.W., et al. (2010). The neuropathology of autism: defects of neurogenesis and neuronal migration, and dysplastic changes. Acta Neuropathol. (Berl.) 119, 755-770.

Williams, K.R., McAninch, D.S., Stefanovic, S., Xing, L., Allen, M., Li, W., Feng, Y., Mihailescu, M.R., and Bassell, G.J. (2016). hnRNP-Q1 represses nascent axon growth in cortical neurons by inhibiting Gap-43 mRNA translation. Mol. Biol. Cell 27, 518-534.

Yang, C.-P., Samuels, T.J., Huang, Y., Yang, L., Ish-Horowicz, D., Davis, I., and Lee, T. (2017). Imp and Syp RNA-binding proteins govern decommissioning of Drosophila neural stem cells.

Development $144,3454-3464$. 
bioRxiv preprint doi: https://doi.org/10.1101/2021.11.06.467542; this version posted November 8, 2021. The copyright holder for this preprint (which was not certified by peer review) is the author/funder, who has granted bioRxiv a license to display the preprint in perpetuity. It is made available under aCC-BY-NC-ND 4.0 International license.

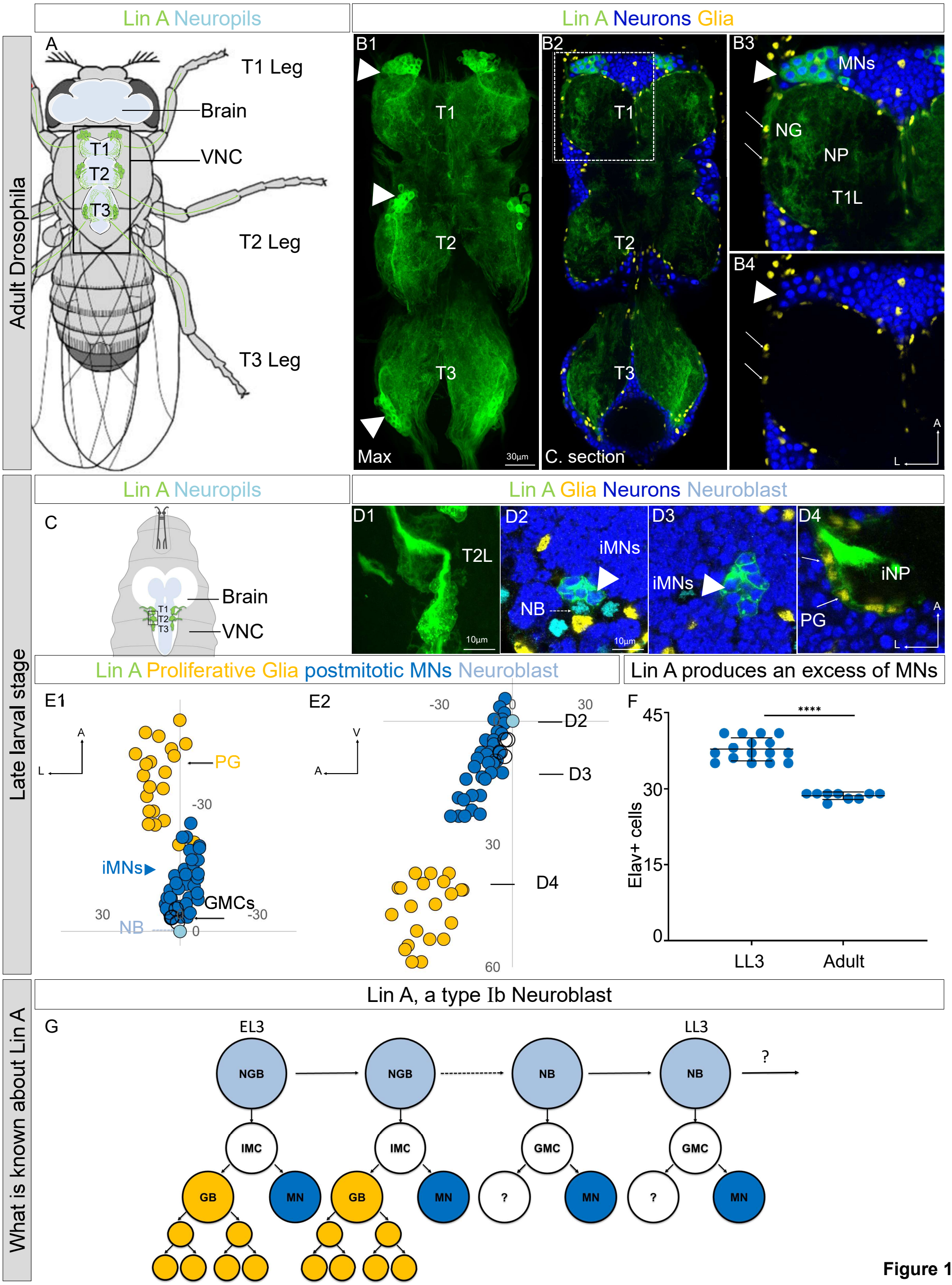


bioRxiv preprint doi: https://doi org/10.1101/2021 11.06.467542; this version posted November 8, 2021. The copyright holder for this preprint (which was not certified by peer review) is the author/funder, who has granted bioRxiv a license to display the preprint in perpetuity. It is made available under aCC-BY-NC-ND 4.0 International license.

Figure 1. Lin A/15 as model to study how a stereotyped number of neurons is produced by a NB

(A) Drawing of an adult fly showing the position of the CNS (white (cortex), blue (neuropiles)) and Lin $\mathrm{A} / 15$ leg MNs (green cell bodies and dendrites in the VNC and axons in the legs). Black box indicates the VNC imaged in $\mathbf{B}$. VNC: ventral nerve cord.

(B1) Maximum projection of confocal sections of an adult VNC where the six Lin A/15s are genetically labeled with mCD8::GFP (green). (B2) Confocal section of the VNC in B1 immunostained with antiElav (neuronal marker, blue) and anti-Repo (glia marker, yellow). T1, T2 and T3 indicate the Prothoracic, Mesothoracic and Metathoracic neuromere respectively. (B3-B4) Confocal section of first left prothoracic neuromere (T1L) (the boxed region in B2), arrowheads and arrows indicate Lin A/15 MN and glia cell bodies, respectively. NG: neuropile glia; NP: neuropile; MN: motor neuron.

(C) Drawing of the anterior region of a third instar larva showing the position of the CNS (white (cortex) blue (neuropiles)) and immature LinA/15 leg MNs (green).

(D1) Maximum projection of confocal sections of the second left thoracic hemisegment (T2L) where Lin A/15 is genetically labeled with mCD8::GFP (green). (D2-D4) Confocal section of the second left thoracic hemisegment (T2L) in (D1) immunostained with anti-Elav (neuronal marker, blue) anti-Dpn (NB marker, cyan) and anti-Repo (glia marker, yellow). Arrowheads, doted arrows and arrows indicate immature Lin A/15 MNs (iMNs), Lin NB and Lin A/15 proliferative glia (PG) respectively. iNP: immature neuropile.

(E1-E2) Graphs of the relative position of each Lin A/15 cell from two perspectives: E1 ventral view, E2 lateral view. Axes: Anterior (A), Lateral (L), Ventral (V). Lin A proliferative Glia (PG) are in yellow, Lin A/15 immature MNs (iMNs) are in blue, Lin A/15 GMCs are in white and Lin A/15 NB is in Cyan. Arrows indicate the positions of the confocal sections in (D2-D4).

(F) Graph of the number of Elav+ MNs in a late third instar larva (LL3) vs that in an adult fly.

(G) Schematic of the Lin A/15 type Ib division. NGB: neuroglioblast, NB: neuroblast, IMC: intermediate mother cell, GMC: ganglion mother cell, GB: glioblast, MN: motoneuron. Note 1: the destiny of the MN sister cell during the second phase of division is unknown. Note 2: Lin A/15 development has not been studied during pupal stages. 
bioRxiv preprint doi: https://doi.org/10.1101/2021.11.06.467542; this version posted November 8, 2021. The copyright holder for this preprint (which was not certified by peer review) is the author/funder, who has granted bioRxiv a license to display the preprint in perpetuity. It is made available under aCC-BY-NC-ND 4.0 International license.

Figure 2. The MN sibling cells die through PCD during the second phase of Lin A/15 NB division

(A1-F3) Graphs and confocal images showing the development of Lin A/15 during larval stages, the developmental time points are indicated on top. (A1, B1, C1, D1, E1, F1): Graphs of the relative position of each Lin A/15 cells in (A2, B2, C2, D2, E2, F2) from a lateral perspective. Axes: Anterior (A), Ventral (V). Lin A/15 proliferative Glia are in yellow, Lin A/15 immature MNs are in blue, Lin A/15 GMCs are in white, Lin A/15 NB is in Cyan, Lin A/15 cDcp1+ cells are in red. The black lines indicate the positions of the confocal section in (A3-F3). (A2, B2, C2, D2, E2, F2): Maximum projection of confocal sections of the second left thoracic hemisegment (T2L) where Lin A/15 is genetically labeled with mCD8::GFP (green). The boxes in (C2-F2) are confocal sections showing Lin A/15 NB immunostained with anti-Dpn (cyan). Note: in A2-B2 the NB is easily recognizable by its size (arrowheads). (A3, B3, C3, D3, E3, F3): Confocal sections of samples in (A2, B2, C2, D2, E2, F2) immunostained with anti- cDcp1(red), anti-Elav (neuronal marker, blue) and anti-Repo (glia marker, yellow) (A2, B2) or with anti-Dpn (NB marker, cyan) (C2, D2, E2, F2) . The boxes in (B3, C3, D3, E3, F3) are magnification of the cDcp1+ (upper box) Elav- (lower box) apoptotic cell.

(G1) Maximum projection of confocal sections of a second right thoracic hemisegment (T2R) with a Lin A/15 MARCM clone genetically labeled with mCD8::GFP (green) under the control of tub-Gal4 and mCherry (red) under the control of Vglut-LexA::GAD. (G2) Confocal section of the second right thoracic hemisegment (T2R) (boxed region in G1) immunostained with anti-Elav (blue) and anti-cDcp1 (cyan). The arrowheads indicate the cDcp1+ Elav-VGlut-apoptotic cell. (G3) Graphs of the relative position of each Lin A/15 cell (excluding the proliferative glia) in (G1) from a lateral perspective. Axes: Anterior (A), Lateral (L), Ventral (V). Lin A/15 immature MNs are in blue (Elav+), the blue cells surrounded in red are the GFP+ Elav + Vglut + immature MNs, the blue cells surrounded in green are the GFP+ Elav+ Vglut- immature MNs (last born MNs) and the cyan cells surrounded in green are the cDcp1+ GFP+ VGlut- Elav- apoptotic cell. Note: the NB (white cell surrounded in green) has been identified by its size. The black line indicates the position of the confocal section in (G2).

(H) Schematic of the Lin A/15 type Ib division. NGB: neuroglioblast, NB: neuroblast, IMC: intermediate mother cell, GMC: ganglion mother cell, GB: glioblast, MN: motoneuron. The markers used to label each type of Lin A cells are indicated. 
bioRxiv preprint doi: https://doi org/10.1101/2021.11.06.467542; this version posted November 8,2021 . The copyright holder for this preprint (which was not certified by peer review) is the author/funder, who has granted bioRxiv a license to display the preprint in perpetuity. It is made available under aCC-BY-NC-ND 4.0 International license.

\section{Figure 3. Lin A/15 NB decommissions at 24h APF through PCD}

(A1-C2) Confocal images showing the development of Lin A/15 during pupal stages, the developmental time points are indicated on top. APF: after pupa formation.

(A1, B1, C1) Maximum projection of confocal sections of the first left thoracic hemisegment (T1L) where Lin A/15 is genetically labeled with mCD8::GFP (green). (A2, B2, C2) Confocal sections showing Lin A/15 immunostained with anti-Elav (blue), anti-Dpn (cyan) and anti-pH3 (red, phosphoHistone3, mitosis-specific marker). On the right of (A2, B2, C2) magnifications of the boxed region in (A2, B2, C2). Arrowheads indicate the proliferative Lin A/15 NBs (Dpn+ pH3+).

(D1) Maximum projection of confocal sections of three thoracic ganglions (T1, T2, T3) at 24h APF where all 6 Lin A/15s are genetically labeled with mCD8::GFP (green). (D2) Confocal section of thoracic ganglions in (D1) immunostained with anti-Elav (blue), anti-Dpn (cyan) and anti-cDcp1 (red). On the right of (D2) magnifications of the boxed region in (D2) (left Mesothoracic neuromere, T2L). Arrowheads indicates the apoptotic Lin A/15 NB (Dpn+ cDcp1+).

(E-F) Confocal images showing the absence vs presence of Lin A/15 NB at 28h APF in Control vs P35 OE contidions.6 Lin A/15s are genetically labeled with mCD8::GFP (green), Lin A/15 NB and MNs are visualized with anti-Dpn (red) and anti-Elav (blue) respectively. Magnifications of the boxed region (first right thoracic hemisegment, T1R) indicate the presence of NB (Dpn+, arrowhead) in P35 OE contidion.

(G) Graph of the frequency of NB presence (Number of Lin A/15 samples analyzed is indicated on each bar) at different developmental time points under different genetic conditions: absence of NB (white), NB presence in Control (green), NB presence in P35 OE (purple).

(H) Schematic of the Lin A/15 type Ib division during larval and pupal stages. NGB: neuroglioblast, NB: neuroblast, IMC: intermediate mother cell, GMC: ganglion mother cell, GB: glioblast, MN: motoneuron. The markers used to label each type of Lin A/15 cells are indicated. 
bioRxiv preprint doi: https://doi.org/10.1101/2021.11.06.467542; this version posted November 8, 2021. The copyright holder for this preprint (which was not certified by peer review) is the author/funder, who has granted bioRxiv a license to display the preprint in

Time
A: 70-73h AEL
B:94-97h AEL
C: 120h AEL
E: 8h APF
F: 23h APF
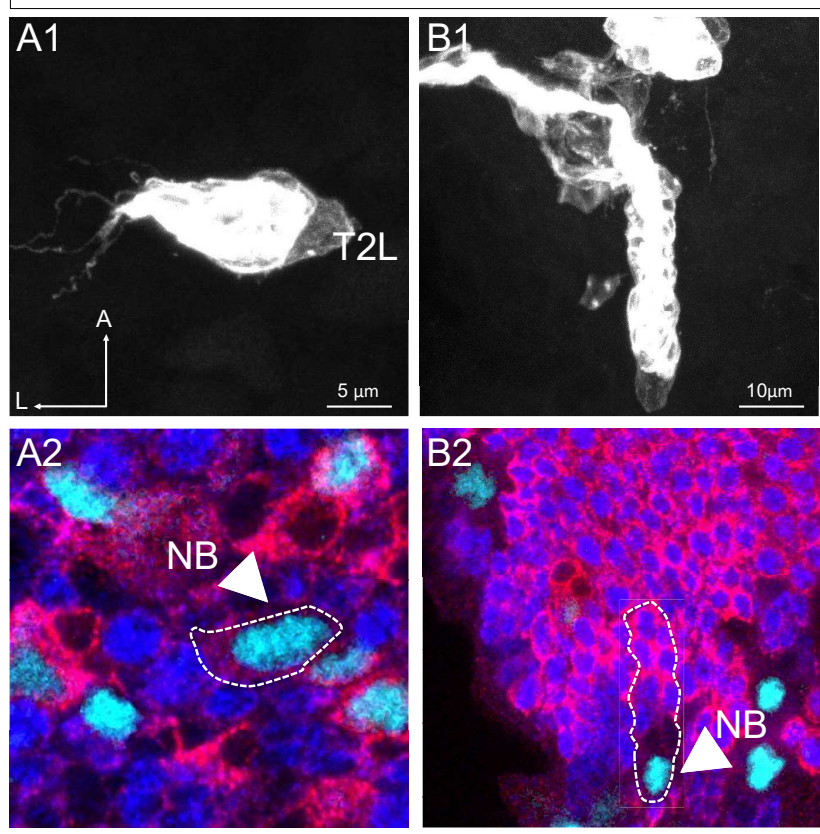

Loin 令 Imp, Elav, Dpn
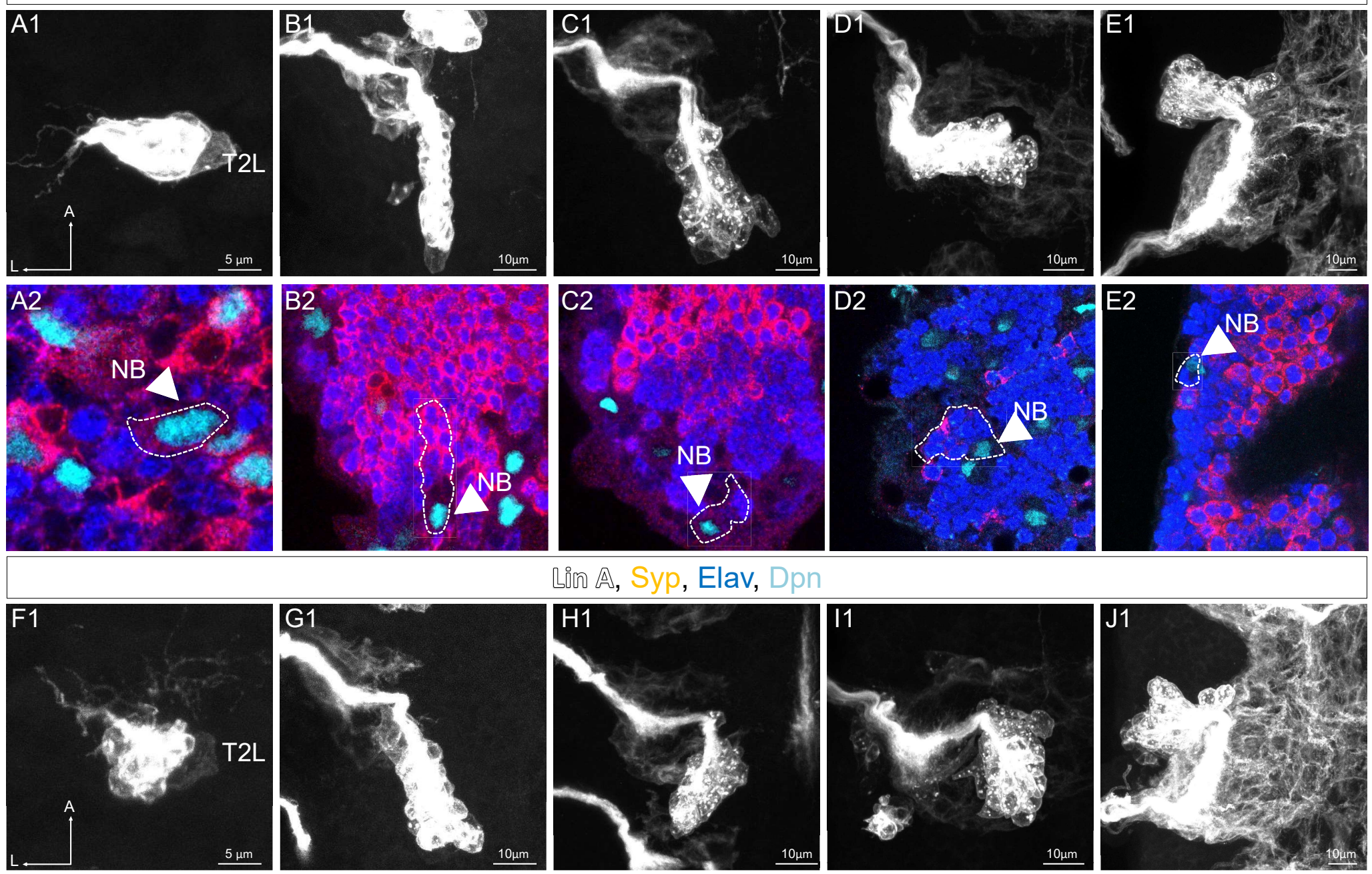

[ion ^A, Syp, Elav, Dpr
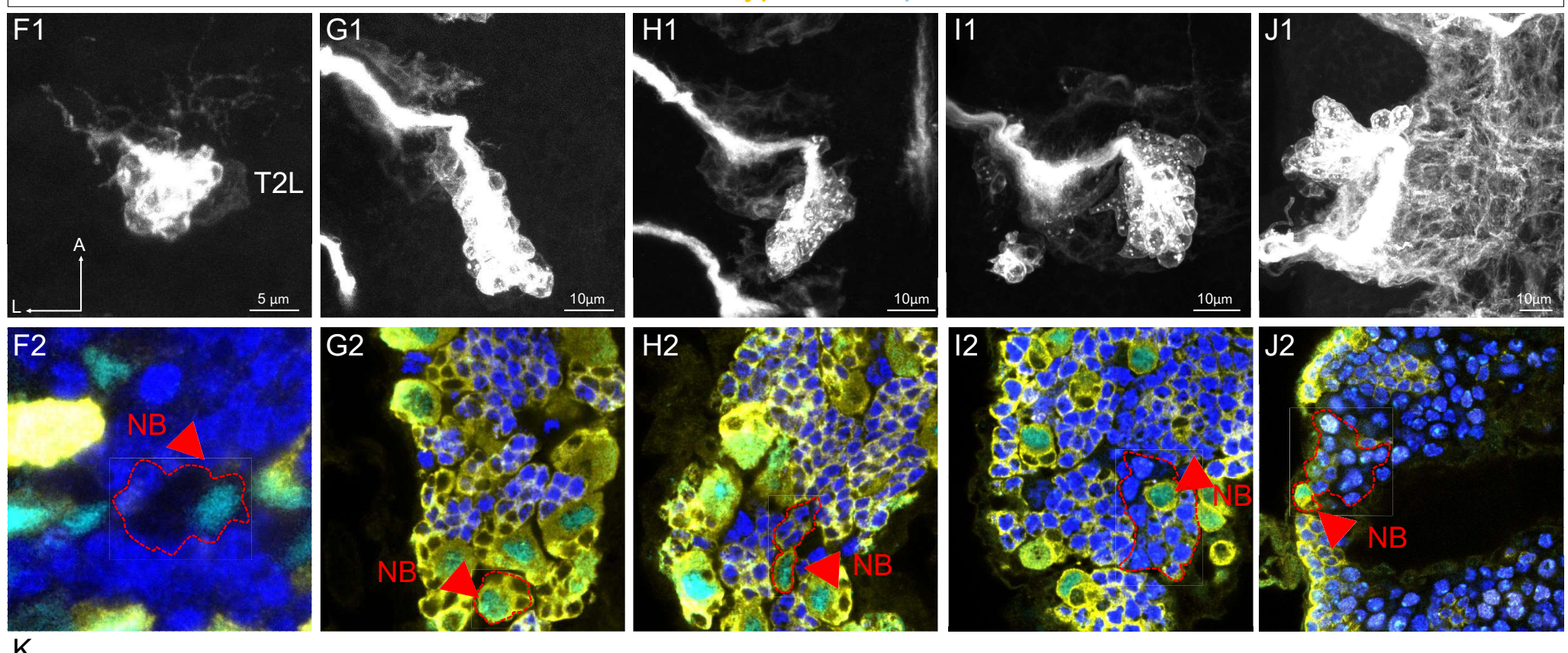
Imp

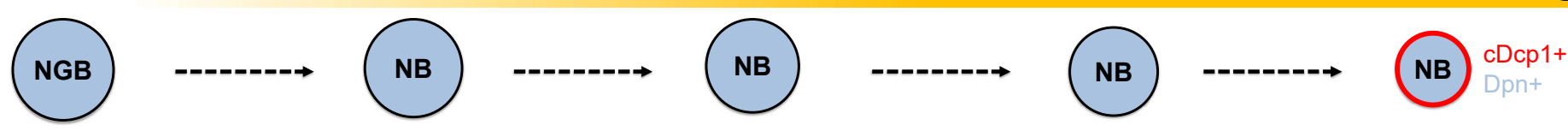


bioRxiv preprint doi: https://doi org/10.1101/2021.11.06.467542· this version posted November 8 , 2021. The copyright holder for this preprint (which was not certified by peer review) is the author/funder, who has granted bioRxiv a license to display the preprint in perpetuity. It is made available under aCC-BY-NC-ND 4.0 International license.

\section{Figure 4. Spatio-temporal expression of Imp/Syp in Lin A/15}

(A1-J2) Confocal images showing the development of Lin A/15 during larval and pupal stages, the developmental time points are indicated on top. AEL: after egg laying; APF: after pupa formation. (A1, B1, C1, D1, E1, F1, G1, H1, I1, J1) Maximum projection of confocal sections of the second left thoracic hemisegment (T2L) where Lin A/15 is genetically labeled with mCD8::GFP (white). (A2, B2, C2, D2, E2, F2 G2, H2, I2, J2) Confocal sections showing Lin A/15 NB in (A1, B1, C1, D1, E1, F1, G1, H1, I1, J1) immunostained with anti-Elav (neuronal marker, blue), anti-Dpn (NB marker, cyan) and antiImp (red) (A2, B2, C2, D2, E2) or anti-Syp (yellow) (F2 G2, H2, I2, J2). The dashed lines indicates GFP labeled cells including NB and new-born MNs. White and red arrowheads indicate Lin A/15 NB.

(K) Schematic of Imp and Syp expression in Lin A/15 NB at different time points. The red and yellow bars indicate the opposite temporal gradients of Imp and Syp respectively in Lin A/15 NB during larval and pupal stages. NGB: neuroglioblast, NB: neuroblast. 
bioRxiv preprint doi: https://doi.org/10.1101/2021.11.06.467542; this version posted November 8, 2021. The copyright holder for this preprint (which was not certified by peer review) is the author/funder, who has granted bioRxiv a license to display the preprint in

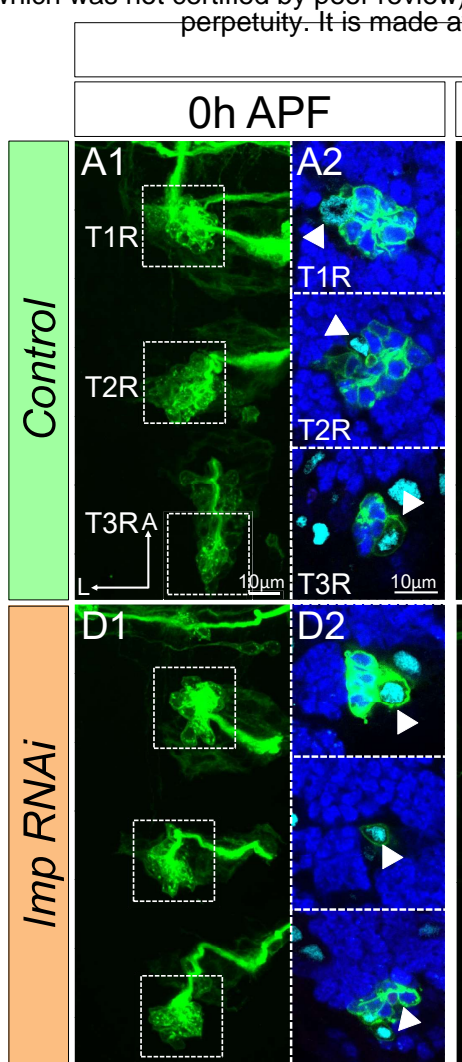
Lin A Elav Dph
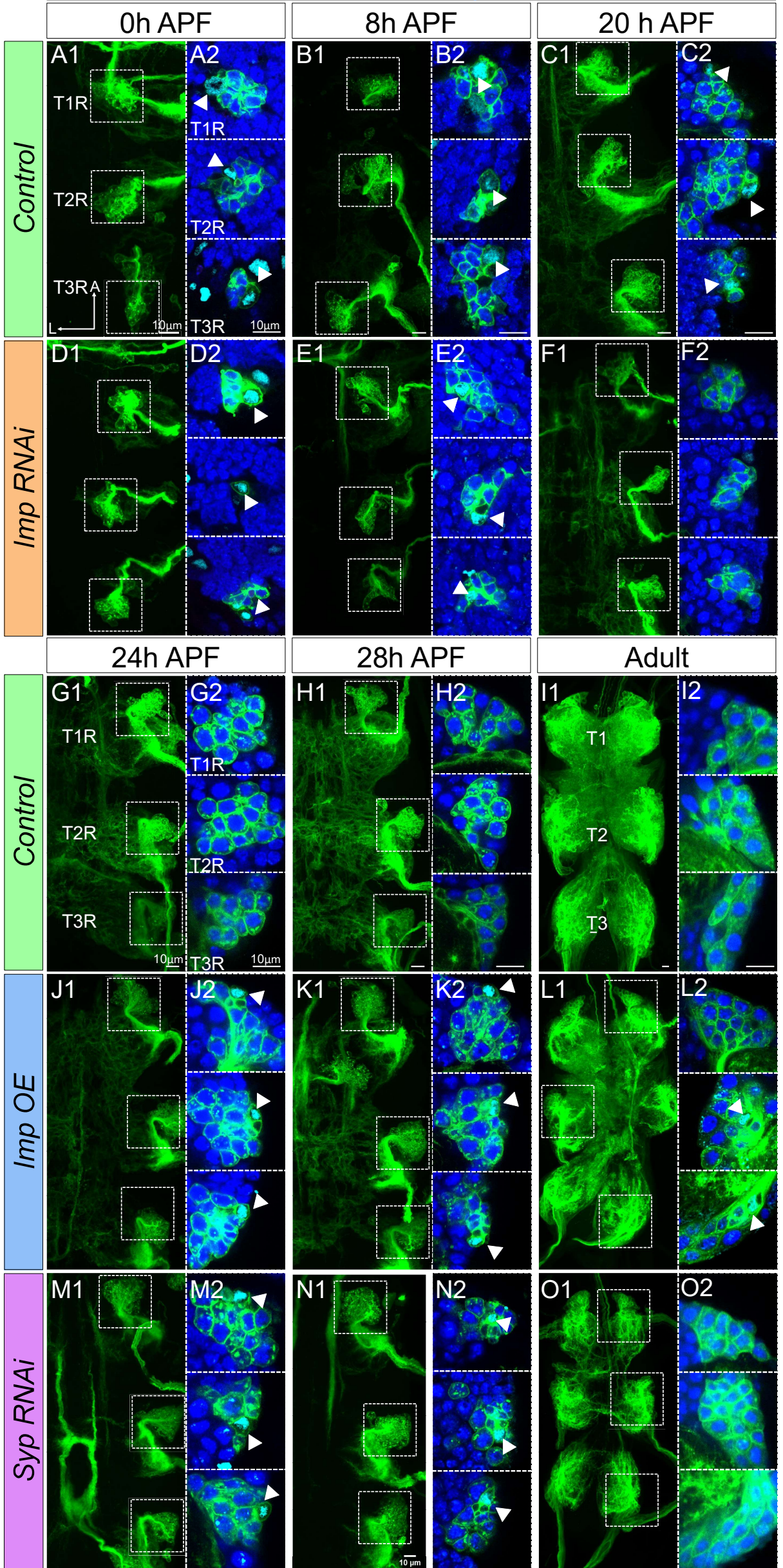

$\bigcirc$ Control $\bigcirc$ Imp RNAi $\bigcirc$ Imp OE $\bigcirc$ Syp RNAi

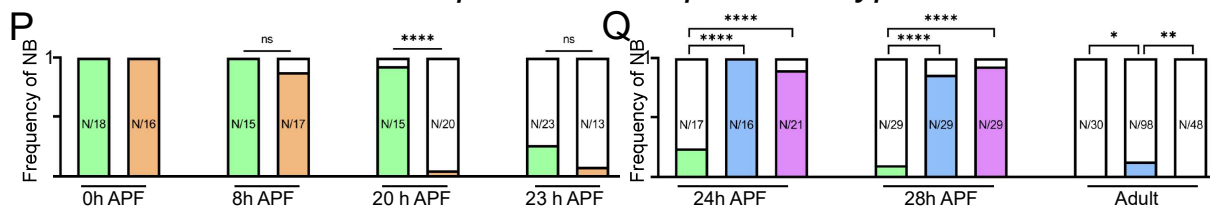


bioRxiv preprint doi: https://doi org/10.1101/2021 11.06.467542. this version posted November 8, 2021. The copyright holder for this preprint (which was not certified by peer review) is the author/funder, who has granted bioRxiv a license to display the preprint in perpetuity. It is made available under aCC-BY-NC-ND 4.0 International license.

Figure 5. Opposite temporal expressions of Imp/Syp control the timing of Lin A/15 NB decommissioning

(A1-O2) Confocal images showing the development of WT (A1-C2, G1-I2), Imp RNAi (D1-F2), Imp $O E$ (J1-L2) and Syp RNAi Lin A/15 (M1-O2) from pupal stages until the adult stage.

(A1, B1, C1, D1, E1, F1, G1, H1, I1, J1, K1, L1, M1, N1, O1) Maximum projection of confocal sections of the three right thoracic hemisegments (T1R, T2R, T3R) during pupal stages (A1, B1, C1, D1, E1, F1, G1, H1, J1, K1, M1, N1) or maximum projection of confocal sections of intact adult VNCs (I1, L1, O1) where Lin A is genetically labeled with mCD8::GFP (green). (A2, B2, C2, D2, E2, F2, G2, H2, I2, J2, K2, L2, M2, N2, O2) Confocal sections of boxed regions in (A1, B1, C1, D1, E1, F1, G1, H1, I1, J1, K1, L1, M1, N1, O1) immunostained with anti-Elav (neuronal marker, blue) and antiDpn (NB marker, cyan). The developmental time points are indicated on the top of each panel. Arrowheads indicate the presence of NB (Dpn+).

(P-Q) Graph of the frequency of NB presence (Number of Lin A/15 samples analysed is indicated on each bar) at different developmental time points under different genetic conditions: absence of NB (white), NB presence in Control (green), NB presence in Imp RNAi (orange), NB presence in Imp OE (blue) and NB presence in Syp RNAi (purple). 
Time

A: Oh APF

B: 8h APF

C: $24 h$ APF

Lin A: NB apoptotic cells motoneurons

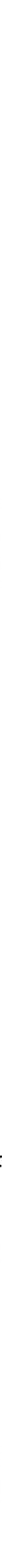


bioRxiv preprint doi: https://doi org/10.1101/2021.11.06.467542; this version posted November 8,2021 . The copyright holder for this preprint (which was not certified by peer review) is the author/funder, who has granted bioRxiv a license to display the preprint in perpetuity. It is made available under aCC-BY-NC-ND 4.0 International license.

\section{Figure 6. The last-born Lin A/15 MNs are eliminated by PCD during early pupal stages.}

(A1-C3) Graphs and confocal images showing the PCD pattern in Lin A/15 MNs during pupal stages, the developmental time points are indicated on top.

(A1, B1, C1) Graphs of the relative position of each Lin A/15 cell of the boxed regions in (A2, B2, C2) from a lateral perspective. Axes: Anterior (A), Ventral (V). Lin A/15 immature MNs are in blue, Lin A/15 GMCs are in white, Lin A/15 NB is in Cyan and cDcp1+ MNs are in red and blue. The black lines indicate the positions of the confocal sections in $(\mathrm{A3}, \mathrm{A4}, \mathrm{B3}, \mathrm{B} 4, \mathrm{C} 3, \mathrm{C4})$.

(A2, B2, C2) Maximum projection of confocal sections of the three thoracic segments (T1,T2,T3) where Lin A/15 is genetically labeled with mCD8::GFP (green). (A3, A4, B3, B4, C3, C4) are confocal sections showing the Elav+, cDcp1+ cells immunostained with anti-Dpn (cyan), anti-Elav (blue) and anti-cDcp1 (red) in the boxed regions in (A2, B2, C2). Arrowheads indicate the apoptotic MNs (Elav+, cDcp1+).

(D) Graph of the number of Elav+ Lin A/15 neurons at different developmental time points.

(E1) Maximum projection of confocal sections of three left thoracic hemisegments at 5 hour APF where Lin A/15 is genetically labeled with mCD8::GFP (green). (E2, E3, E4) Confocal sections of the three left thoracic hemisegments (boxed regions in (E1)) immunostained with anti-cDcp1(red), anti-Elav (neuronal marker, blue) and Edu (yellow). Arrowheads indicate the Elav+, cDcp1+ Edu+ cells. Note: the larvae were fed with Edu from 98 to 120h AEL to label only the last born motoneurons with Edu (close to the NB). The cDcp1+ Elav+ cells are always Edu+. (E5, E6, E7) Graphs of the relative position of each Lin A/15 cell of the boxed regions in (E1) from a lateral perspective. Axes: Anterior (A), Ventral (V). Lin A/15 immature MNs are in blue, Lin A/15 GMCs are in white, Lin A/15 NB is in Cyan and Elav+, cDcp1+ cells are in red and blue, Edu+ cells are circled in yellow. Note: the last born MNs and the GMCs as well as NB are all Edu+ (circled yellow)and the apoptotic Elav+ cDcp1+ cells is always part of this population of Edu + cells demonstrating that the last born MNs are dying.

(F) Graph of the number of Edu+ Lin A/15 MNs at 5h APF and 17h APF, of which larvae are fed with Edu from 98 to 120 hours AEL. Note: the number of Edu+ cells neurons decrease significantly between $5 \mathrm{~h}$ and $17 \mathrm{~h}$ APF demonstrating that the last born MNs are eliminated.

(G) Graph of the number of Elav + VGlut + Lin A/15 cells in third instar larvae (LL3) and adults (Adult) of $W T$ vs $V G l u t>P 35$ Lin A/15 MARCM clones.

(H-K) Maximum projection of confocal sections of the left T1 segment (T1L) of third instar larva (HI) and the left prothoracic neuromere (T1L) in adult fly (J-K) containing a WT (H, J) or a VGlut $>$ P35 $(\mathbf{I}, \mathbf{K})$ Lin A/15 MARCM clone. The boxed regions inserted in each picture in (H-K) indicate the Elav + GFP+ cells.

(L) Schematic of the Lin A/15 type Ib division during larval and pupal stages. NGB: neuroglioblast, NB: neuroblast, IMC: intermediate mother cell, GMC: ganglion mother cell, GB: Glioblast, MN: motoneuron. 
bioRxiv preprint doi: https://doi.org/10.1101/2021.11.06.467542; this version posted November 8,2021 . The copyright holder for this preprint (which was not certified by peer review) is the author/funder, who has granted bioRxiv a license to display the preprint in perpetuity. It is made available under aCC-BY-NC-ND 4.0 International license.

Figure 7. The opposite expression pattern in immature neurons of Imp/Syp instructs the number of MN surviving

(A1) Maximum projection of confocal sections of the T1R hemisegment where Lin A/15 is genetically labeled with mCD8::GFP (green) at 5h APF. (A2, A3, A4, A5) are confocal sections of the Lin A/15 in (A1) showing the apoptotic MN immunostained with anti-Imp (red), anti-Elav (blue) and anti-cDcp1 (cyan) of (A1). Arrowheads indicate the apoptotic MN (Elav+, cDcp1+) is absent of Imp (Imp-).

(B1-B2) Graph of the number of apoptotic MNs (Elav+, cDcp1+) observed in Lin A/15 at different developmental time points under different genetic conditions: Control (green), Imp RNAi (orange), Imp $O E$ (blue) and Syp RNAi (purple).

(C1, D1, E1, F1, G1, H1, I1, J1) Maximum projection of confocal sections of the second right thoracic hemi-segments (T2R) where Lin A/15 is genetically labeled with mCD8::GFP (green) under different genetic conditions $W T(\mathbf{C 1}, \mathbf{E 1}, \mathbf{H 1}), \operatorname{Imp} R N A i$ (D1), Imp OE (F1, I1,) and Syp RNAi (G1, J1). (C2, D2, E2, F2, G2, H2, I2, J2) Confocal sections of the second right thoracic hemisegment (T2R) in (C1, D1, E1, F1, G1, H1, I1, J1) immunostained with anti- cDcp1(red), anti-Elav (neuronal marker, blueand anti-Dpn (NB marker, cyan). The boxed region in (D2, E2, H2, J2) indicated the presence of Elav+ cDcp1+ cells. (C3, D3, E3, F3, G3, H3, I3, J3) Graphs of the relative position of each Lin A/15 cell in (C1, D1, E1, F1, G1, H1, I1, J1) from a lateral perspective. Axes: Anterior (A), Ventral (V). Lin A/15 immature MNs are in blue, Lin A/15 GMCs are in white, Lin A/15 NB is in Cyan and cDcp1+ Elav+ neurons are in red and blue.

(K) Graph of the number of Elav+ Lin A/15 neurons observed in adult flies under different genetic conditions: WT (green), Imp RNAi (orange), Imp OE (blue) and Syp RNAi (purple).

(L1-M1) Maximum projection of confocal sections of the left prothoracic neuromere (T1L) containing a WT (L1) or a $V G l u t>\operatorname{Imp}$ (M1) Lin A/15 MARCM clone. The boxed regions in (L1-M1) are confocal sections showing the Lin A/15 Elav+( anti-Elav, Blue) GFP+ cells. (L2-M2) Graphs of the relative position of each Lin A/15 cell in (L1, M1) from a lateral perspective. Axes: Anterior (A), Ventral (V). Lin A/15 immature MNs are in blue.

(N) Graph of the number of Elav $+V G l u t+$ Lin A/15 cells of WT and VGlut $>\operatorname{Imp}$ Lin A/15 MARCM clones in third instar larvae (LL3) and adult flies(Adult). 


\section{Time: 3 days of development}

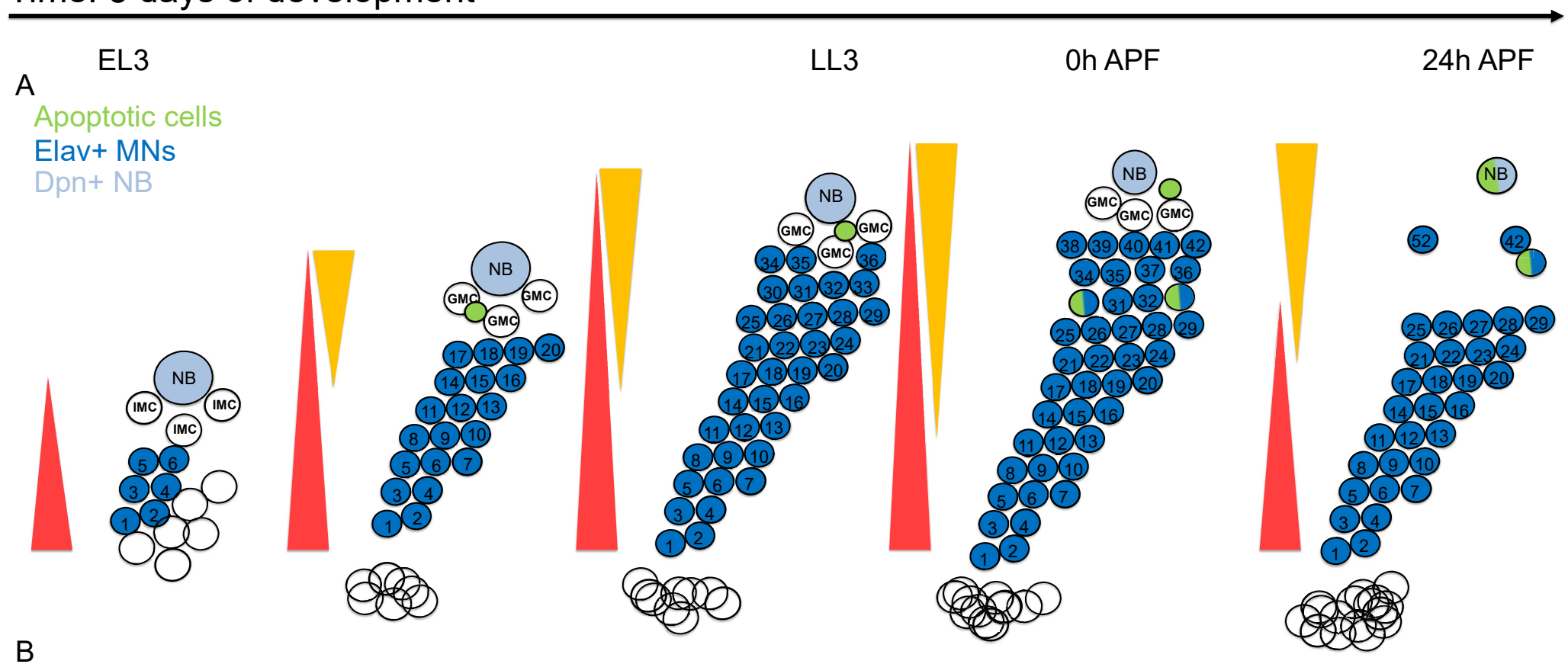

B

Imp

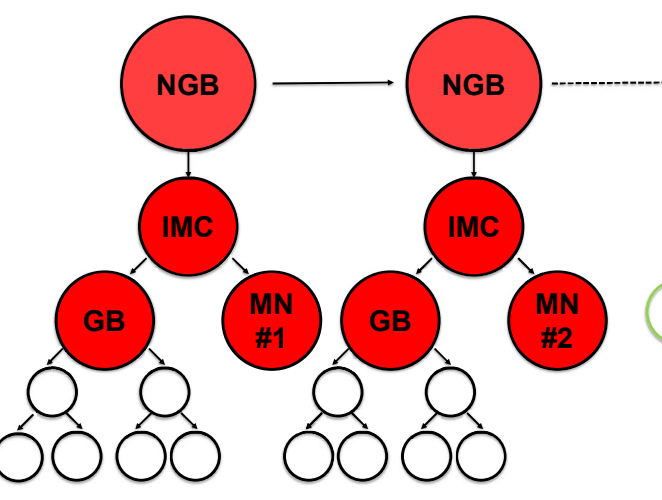

Imp + $\mathrm{cDcp} 1+$

Syp + † Apoptosis

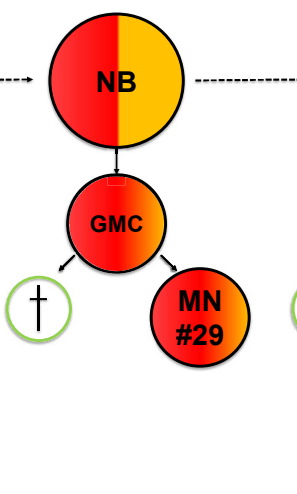

(c)

Elimination of MNs after 29 divisions during pupal stages 
bioRxiv preprint doi: https://doi org/10.1101/2021.11.06.467542; this version posted November 8,2021 . The copyright holder for this

\section{Figure 8. Intrinsic Imp/Syp level instructs spatiotemporal PCD Pattern.}

(A) Schematic of Lin A/15 at different developmental time points correlating Imp/Syp protein level and spatio-temporal PCD pattern in Lin A/15 cells. Sequential expression of Imp and Syp in Lin A/15 NB times precisely the decommissioning of Lin A/15. Pupal Lin A/15 NB is abundant of Syp and with undetectable Imp, the NB undergoes progressive size reduction and is eliminated by apoptosis ar $24 \mathrm{~h}$ APF. The serially derived MNs inherits Imp/Syp expression from the NB, the expression of Imp in the first-born 29 MNs protects them from PCD throughout pupal stages, while the presence of Syp in the last-born MNs promotes them undergoing progressive apoptosis.

(B) Schematic of the Lin A/15 type Ib division correlating Imp/Syp protein level and spatio-temporal PCD pattern in Lin A/15 cells. 